\title{
AFRICAN EAST-ASIAN AFFAIRS
}

THE CHINA MONITOR

\section{Issue 2 | June 2014}

\author{
Jean-Pierre Cabestan
}

Gabon-China relations: towards a more cautious partnership

Suweon Kim

Mao's new democracy and Ghana's foreign policy change in 1983

Okolo Abutu Lawrence

From non-interference to preponderance:

China's future grand strategy in Africa

FORUM:

Liang Yijian

Leading to environmental sustainability: current status, challenges and prospects of Sino-African low-carbon co-operation

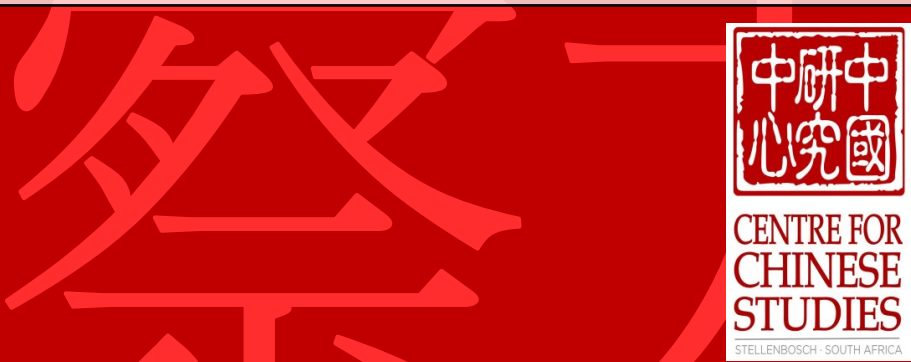


AFRICAN

EAST-ASIAN

AFFAIRS

\section{Editorial Board of the African East-Asian Affairs}

Chris ALDEN, London School of Politics and Economics/ South African Institute of International Affairs Adams BODOMO, Vienna University

Fantu CHERU, American University and Leiden University

$$
\text { Scarlett CORNELISSEN, Stellenbosch University }
$$

Stephen GELB, World Trade Institute, University of Bern Karen HARRIS, University of Pretoria

Garth LE PERE, University of Pretoria and Gabriel \& Associates

LI Xiaoyun, China Agricultural University

$$
\begin{aligned}
& \text { LIU Haifang, Peking University } \\
& \text { MINE Yoichi, Doshisha University } \\
& \text { HUANG Meibo, Xiamen University }
\end{aligned}
$$

Kyu Deug HWANG, Hankuk University of Foreign Studies

Yoon Jung PARK, Rhodes University (non-resident)/ Chinese in Africa/Africans in China Research Network Ian TAYLOR, University of St. Andrews Chen-shen YEN, National Chengchi University Taipei ZHANG Chun, Shanghai Institutes for International Studies 


\section{African East-Asian Affairs}

Issue 2 | June 2014

The African East-Asian Affairs (AEAA) is an international, African based journal. It focuses on the developments and nuances of the relationship between Africa and EastAsian nations, including China, Japan, Korea and the ASEAN states. Topics covered include both the domestic developments and the international relations of these states, with a focus on their engagement with Africa. Articles published fall within the social sciences and related disciplines, such as politics, economics, environmental studies and law. The AEAA was formerly known as the China Monitor, a title that has now been reserved for special topical issues only. The journal has been in circulation since 2006 . The AEAA in its current form was re-launched in 2012.

\section{Submissions to African East-Asian Affairs:}

The CCS welcomes contributions for this publication. Please contact the editors using the details below if you would like to submit a piece, or would like guidelines on submissions to African East-Asian Affairs. The CCS reserves the right not to publish submitted manuscripts.

$$
-0
$$

\section{Editorial Team}

Dr Sven Grimm | Editor-in-Chief

Harrie Esterhuyse | Deputy Editor

(C) Centre for Chinese Studies, Stellenbosch University, 2014. All Rights Reserved.

\section{Centre for Chinese Studies}

Stellenbosch University

Tel: $+27(0) 218082840$

P.O. Box 3538 Matieland

Fax: +27 (0) 218082841

7602

Email: aeaa@sun.ac.za

South Africa

Website: aeaa.journals.ac.za 
\begin{tabular}{|c|l}
\hline AFRICAN & Issue 2 \\
EAST-ASIAN & June 2014 \\
AFFAIRS & \\
\hline THE CHINA MONITOR & \\
\hline
\end{tabular} 


\section{Contents}

Issue 2 | June 2014

Jean-Pierre Cabestan .06

Gabon-China relations: towards a more cautious partnership

Suweon Kim

Mao's new democracy and Ghana's foreign policy change in 1983

Okolo Abutu Lawrence. .62

From non-interference to preponderance: China's future grand strategy in Africa

\section{Forum:}

Liang Yijian

Forum: Leading to environmental sustainability: current status, challenges and prospects of Sino-African low-carbon co-operation 
AFRICAN

\title{
Gabon-China relations: towards a more cautious partnership*
}

\author{
By Jean-Pierre Cabestan** \\ Department of Political Science \\ Hong Kong Baptist University, SAR Hong Kong
}

\begin{abstract}
As early as in the 1970s, the then Gabonese president Omar Bongo Ondimba, although very close to France, decided to diversify his country's external partnerships. The development of dynamic diplomatic and, since the 1990s, economic relations with China was part of this strategy. And since he succeeded his father in 2009, Ali Bongo has continued and even deepened this diversification policy. Yet, Gabon's strategy as well as domestic political pressure, have contributed to setting limits to its diplomatic and economic partnership with China. In other words, Gabon offers an instructive case of how domestic politics and foreign policy priorities can influence an African country's relations with the world second great power and economy. Having said that, much wealthier and less populated than many other African nations and enjoying more options than many of them, Gabon may remain a special case.
\end{abstract}

*This research was funded by the Research Grant Council of Hong Kong Special Administrative Region (GRF No. HKBU 240110)

**Jean-Pierre Cabestan is Head of Department at the Department of Political Science at Hong Kong Baptist University in SAR Hong Kong. 


\section{Introduction}

Gabon is still seen by some observers as the symbol of the Françafrique, this cosy and often incestuous relationship between France and its former colonies in Africa (Yates, 1996; Benquet, 2011). Although relations between Libreville and Paris have remained very close and France continues to hold regular summits with its African partners, the old, traditional Françafrique has been gone for a long time, including in Gabon. As early as the 1970s, the then Gabonese president Omar Bongo Ondimba, although handpicked by the French government, decided to diversify his country's external partnerships. The development of dynamic diplomatic and, since the 1990s, economic relations with China was part of this strategy (Michel and Beuret 2010: 147-75). And since he succeeded his father in 2009, Ali Bongo has continued and even deepened this diversification policy. As a result, in the last twenty years, Gabon-China trade has decupled, Chinese infrastructure projects and investments in this resource-rich African country have surged; economic and political co-operation has consolidated, turning Gabon into a privileged destination for Chinese business and political leaders.

Yet, Gabon's strategy of international diversification and, more recently, the pressure of a more assertive civil society have contributed to setting limits to its diplomatic and economic partnership with China. Elected under dubious circumstances with only 42 per cent of the vote in 2009 and contested by influential opposition figures, President Ali Bongo needs to convince the electorate of his achievements before the next election in 2016. Simultaneously, some disappointments with Chinese companies have also contributed to this change of mind. In 2012-2013, two major "push backs" occurred (Addax and Bélinga), as a result of Chinese companies' unwelcomed practices or inability to fulfil their commitment. And more globally, in spite of the mega-projects in which China has been involved, its image among the Gabonese elites and society has remained controversial, creating a distance, if not a mistrust. As a result, Ali Bongo has appeared less enthusiastic than his father about privileging co-operation with China. In other words, Gabon offers an instructive case of how domestic politics and foreign policy priorities can influence an African country's relations with the world second great power and econo- 
AFRICAN

AFFAIRS

my. Having said that, much wealthier [US\$ 10,000 Gross Domestic Product (GDP)/per capita] and less populated (1.67 million) than other African nations and enjoying more options than many of them, Gabon may remain a special case.

This article is based on fieldwork and interviews conducted in Gabon in January 2014 as well as published first-hand and second-hand materials. It aims at holistically analysing the more recent dynamic of Gabon-China relations and the place it occupies in Gabon's diplomacy and economic development strategy.

\section{Background of Gabon-China relations}

After the establishment of diplomatic relations between Gabon and China in 1974, relations between both countries remained for a long time driven more by political

\section{Map 1: Gabon with major cities and neighbouring countries}

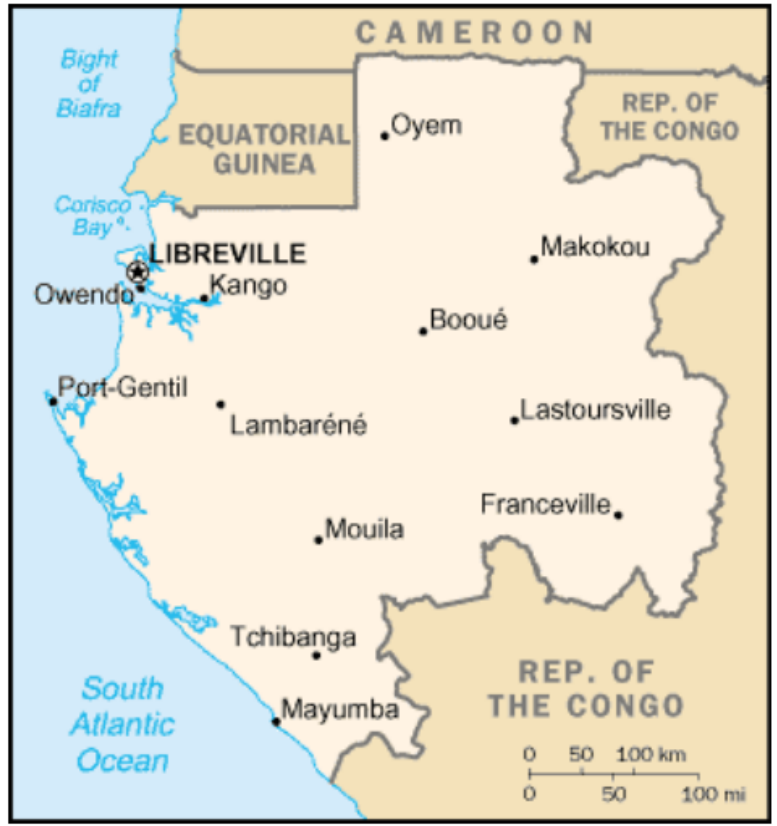

(C) Centre for Chinese Studies, Stellenbosch University 
rather than economic considerations. Although Omar Bongo visited China eleven times (in 35 years), trade was limited and the Chinese presence in Gabon was restricted to a handful of symbolic infrastructure projects, such as the National Assembly, built in 2002. The real turning point took place in 2004 when President Hu Jintao visited Gabon.

\section{The 2004 turning point}

After 2004, the Chinese authorities continued to deliver turnkey iconic buildings as the Stade de l'Amitié sino-gabonaise (Sino-Gabonese Friendship Stadium), completed right on time for the 2012 Coupe d'Afrique des Nations (African Cup of Nations). But at the same time they started to get more interested in the extraction of Gabon's rich natural resources, particularly oil, timber and iron ore, and involved in its economic development plan. Two large deals were signed, the first one to guarantee a minimum supply of crude oil to China, the second one between Unipec, a subsidiary of Sinopec, and Total Gabon for oil exploration and refining in Gabon. While remaining modest, Chinese oil imports from Gabon increased to nearly US\$1 billion in 2009.

In the extractive industries sector, China's interest for the untapped iron ore mine of Bélinga became obvious when in 2005 a consortium led by CMEC (China National Machinery and Equipment Import and Export Corporation) and financially supported by the Eximbank, displaced the one led by Companhia Vale do Rio Doce (CVRD, better known as Vale) from Brazil and was granted, a year later, the sole rights to develop this mining complex (Yates, 2008:216-220). We will discuss the Bélinga saga below, but suffice is to indicate here that the Chinese offer, a package deal of US\$3 billion, was highly attractive, including the construction of two dams, a new railway line $(560 \mathrm{~km})$ all the way to Santa Clara and a new harbour in the coastal city located north of Libreville.

At the same time, China having become a large importer of manganese (including from Gabon), two Chinese companies decided to join forces to try to get into the extraction business of this mineral. After having set up a Sino-Gabonese jointventure called Compagnie industrielle et commerciale des mines de Huazhou 
(CICMH or Huazhou Industrial and Commercial Mining Company), this company received a license in 2007 to prospect and exploit manganese in the M'Bembélé Mountains, 36 kilometres $(\mathrm{km})$ from Ndjole, a city located on the Transgabonais railway $150 \mathrm{~km}$ east of Libreville, and build a port next to COMILOG's in Owendo, south of the capital (Jansson et al., 2009:18). The Chinese investment amounted to US\$ 420 million to US\$ 560 million, including a US\$ 84 million loan provided by its main shareholder, Huazhou Mining Investment Company at an interest rate of 6.5 per cent ${ }^{1}$.

In the infrastructure sector, China intensified its presence with the signing in 2008 of an agreement for the building of the Grand Poubara dam $15 \mathrm{~km}$ outside of Franceville in the province of Haut-Ogooué, more than $700 \mathrm{~km}$ southwest of Libreville, an area where the Compagnie minière de l'Ogooué's (COMILOG) main manganese mine is located. Built in 56 months by PowerChina, a subsidiary of Sinohydro under an engineering-procurement-construction basis, this dam started to operate in September 2013. Financed by a concessional loan of US\$ 83 million to be reimbursed over 20 years at a 3 per cent interest rate with a grace period of 7 years, this dam will have a $160 \mathrm{MW}$ capacity when in full operation (Alves, 2008:10; Interview 2, January 2014) 2 .

Although it would be an exaggeration to qualify the strengthening of the Libreville -Beijing relations after 2004 as an "axis", on both sides there was a clear willingness to give more economic substance to their political partnership (Dittgen, 2011b: 8).

\section{From Omar to Ali Bongo: the limits of the Sino-Gabonese rapprochement}

It is clear that already under Omar Bongo, the Gabonese authorities did not want to become too dependent upon China. Then Foreign Minister Jean Ping, although of Chinese descent, was himself candid about the fact that, in his view, China would never replace France (Centre for Chinese Studies, 2007:75). Nevertheless, after Ali Bongo succeeded his father, Gabon readjusted its relations with China and decided to set limits to its partnership with China and its role in Gabon's development plan (Interviews 1, 3, 4, 5 and 12, January 2014). Or to be more accu- 
rate, Ali Bongo has used his connections in the United States, actually more so than in France, to balance as well as better scrutinise Chinese companies' activities in Gabon. For instance, in 2010, he set up a National Infrastructure Agency (Agence Nationale des Grands Travaux or ANGT). Its role is to identify, plan, manage and implement all major public infrastructure projects. He asked the US (Californian) engineering corporation, Bechtel, to provide ANGT with technical expertise and supervise them. Equipped with a very cosmopolitan staff of 350 and a budget of US\$ 200 million, Bechtel has strengthened Ali Bongo's supervision of all the important "priority projects" (180 identified, 90 selected) and contributed to introducing more transparency and accountability as well as to limiting waste, corruption and kickbacks (Interview 2, January 2014).

That does not mean that Sino-Gabonese relations have become colder. High-level political contacts have continued to be quite regular and warm. In the Spring of 2010, President Ali Bongo travelled to China on the occasion of the opening of the World Expo in Shanghai, an exhibition that his Prime Minister, Paul Biyoghe Mba visited in July of the same year ${ }^{3}$. But the rhythm of official visits, especially at the presidential level seems to have slowed down and the whole relationship has become less warm and more pragmatic.

\section{Economic relations: trade and investments}

\section{Bilateral trade}

While since 2008 China has become Gabon's second largest client ahead of France (with the USA as the largest), it has remained its third largest trade partner, because Gabon still imports a lot of goods, especially food products, from its former colonial master.

After rapid progression in the 2000s in trade volumes, China accounted for a 7.2 per cent ( 7.9 per cent according to Chinese statistics) share of Gabon's total volume of merchandise trade by 2012. China was still clearly behind the USA (44.8 per cent) and the European Union as a whole (31 per cent), but closing up with France (9.1 per cent) (Table 1). Gabon continues to export most of its products, 
AFRICAN

especially oil and mineral products, to the USA (59 per cent) and the EU (18 per cent) while only 8 per cent go to China and 2.3 per cent to France (cf. Table 2).

In terms of imports, Gabon buys most of the goods it needs from Europe (65 per cent) and particularly France (27.2 per cent). Whilst driven by an increasing number of Chinese projects, purchases from China are probably higher than local statistics indicate (cf. Table 1). Officially they do not represent more than 12 per cent of Gabon's total imports. ${ }^{5}$. The major imported items from China are mechanical and electrical appliances, construction materials and machinery. Moreover, since 2003, bilateral trade progression between China and Gabon has been fast but irregular, affected by the financial crisis and, after 2010, the export ban imposed on unprocessed wood; since then manganese rather than oil and timber production have

Table 1: Comparison of Gabon's total trade volumes with China, 2003 - 2012 (Million US Dollars)

\begin{tabular}{|c|c|c|c|c|c|c|c|c|c|}
\hline \multirow{2}{*}{ Year } & \multicolumn{3}{|c|}{ China } & \multicolumn{3}{c|}{ WTO } & \multicolumn{3}{c|}{ UN } \\
\cline { 2 - 11 } & Exports & Imports & Total & Exports & Imports & Total & Exports & Imports & Total \\
\hline 2003 & 301 & 9 & 310 & - & - & - & - & - & - \\
\hline 2004 & 400 & 14 & 414 & - & - & - & 175 & 15 & 190 \\
\hline 2005 & 352 & 41 & 393 & 310 & - & 310 & 203 & 25 & 228 \\
\hline 2006 & 817 & 64 & 881 & 594 & 45 & 639 & 636 & 45 & 681 \\
\hline 2007 & 1,095 & 103 & 1,198 & 652 & 59 & 710 & 600 & 83 & 682 \\
\hline 2008 & 1,793 & 138 & 1,931 & 922 & 64 & 986 & 1,260 & 101 & 1,361 \\
\hline 2009 & 719 & 155 & 873 & 541 & 57 & 598 & 428 & 122 & 550 \\
\hline 2010 & 967 & 206 & 1,173 & 750 & 146 & 896 & - & - & - \\
\hline 2011 & 576 & 270 & 846 & 960 & 186 & 1,146 & - & - & - \\
\hline 2012 & 618 & 427 & 1,045 & 773 & 178 & 951 & - & - & - \\
\hline
\end{tabular}

Sources: China Commerce Yearbook 2013, China Commerce and Trade Press; UN Comtrade Database, 2013; World Trade Organization Trade Profiles, from 2006 to 2013. 
spurred Gabon's exports to China, which buys 25 per cent of Gabon's manganese production. Conversely, as $15^{\text {th }}$ African exporter to China and $32^{\text {nd }}$ African importer from China in 2012, Gabon is not one of China's key trade partners in Africa (China Commerce Yearbook, 2013: 72-74).

Table 2: Gabon's merchandise trade with selective partners (Million US Dollars) 4

\begin{tabular}{|c|c|c|c|c|c|c|c|}
\hline \multirow{5}{*}{$\begin{array}{c}\text { By } \\
\text { Destination / } \\
\text { Origin }\end{array}$} & Gabon's Merchandise Trade & \multicolumn{2}{|c|}{2005} & \multicolumn{2}{|c|}{2008} & \multicolumn{2}{|c|}{2012} \\
\hline & Total Volumes & \multicolumn{2}{|c|}{6,313} & \multicolumn{2}{|c|}{11,150} & \multicolumn{2}{|c|}{13,296} \\
\hline & Total Exports & \multicolumn{2}{|c|}{4,920} & \multicolumn{2}{|c|}{8,700} & \multicolumn{2}{|c|}{9,665} \\
\hline & Total Imports & \multicolumn{2}{|c|}{1,393} & \multicolumn{2}{|c|}{2,450} & \multicolumn{2}{|c|}{3,631} \\
\hline & Balance & \multicolumn{2}{|c|}{3,527} & \multicolumn{2}{|c|}{6,250} & \multicolumn{2}{|c|}{6,034} \\
\hline \multirow[t]{4}{*}{ US } & Total (\% of total volumes) & 2,475 & $39.2 \%$ & 5,260 & $47.2 \%$ & 5,960 & $44.8 \%$ \\
\hline & Exports (\% of total exports) & 2,411 & $49 \%$ & 5,081 & $58.4 \%$ & 5,702 & $59.0 \%$ \\
\hline & Imports (\% of total imports) & 64 & $4.6 \%$ & 179 & $7.3 \%$ & 258 & $7.1 \%$ \\
\hline & Balance & \multicolumn{2}{|l|}{2,347} & \multicolumn{2}{|l|}{4,902} & \multicolumn{2}{|l|}{5,444} \\
\hline \multirow[t]{4}{*}{$\mathbf{E U}$} & Total (\% of total volumes) & 1,629 & $25.8 \%$ & 2,692 & $24.1 \%$ & 4,094 & $30.8 \%$ \\
\hline & Exports (\% of total exports) & 679 & $13.8 \%$ & 1,053 & $12.1 \%$ & 1,730 & $17.9 \%$ \\
\hline & Imports (\% of total imports) & 950 & $68.2 \%$ & 1,639 & $66.9 \%$ & 2,364 & $65.1 \%$ \\
\hline & Balance & \multicolumn{2}{|l|}{-271} & \multicolumn{2}{|l|}{-586} & \multicolumn{2}{|l|}{-634} \\
\hline \multirow[t]{4}{*}{ China } & Total (\% of total volumes) & $/$ & $/$ & 986 & $8.8 \%$ & 951 & $7.2 \%$ \\
\hline & Exports (\% of total exports) & 310 & $6.3 \%$ & 922 & $10.6 \%$ & 773 & $8.0 \%$ \\
\hline & Imports (\% of total imports) & 1 & / & 64 & $2.6 \%$ & 178 & $4.9 \%$ \\
\hline & Balance & \multicolumn{2}{|l|}{ / } & \multicolumn{2}{|l|}{858} & \multicolumn{2}{|l|}{595} \\
\hline \multirow[t]{4}{*}{ France } & Total (\% of total volumes) & 804 & $12.7 \%$ & 1,482 & $13.3 \%$ & 1,210 & $9.1 \%$ \\
\hline & Exports (\% of total exports) & 234 & $4.8 \%$ & 574 & $6.6 \%$ & 221 & $2.3 \%$ \\
\hline & Imports (\% of total imports) & 570 & $40.9 \%$ & 908 & $37.1 \%$ & 989 & $27.2 \%$ \\
\hline & Balance & \multicolumn{2}{|l|}{-336} & \multicolumn{2}{|l|}{-334} & \multicolumn{2}{|l|}{-768} \\
\hline
\end{tabular}

Sources: OECD Stat, 2014; China Commerce Yearbook 2013, China Commerce and Trade Press; UN

Comtrade Database, 2013; World Trade Organization Trade Profiles, from 2006 to 2013. 
AFRICAN

AFFAIRS

\section{Chinese investments in Gabon}

Since 2004, China has been involved in a growing number of projects. However, its direct investments in Gabon have remained rather small, its stock amounting to US\$128 million in 2012 or 3 per cent of the overall FDI in Gabon: close to the US level of 3.7 per cent. It has also remained far behind France at 41.7 per cent (Table $3)$. And while the export ban of unprocessed wood was probably responsible for the 2011 drop, the FDI inflow trend has not yet shown a clear increase in China's share which was at 4.4 per cent in 2012 (Table 4).

Among the recent Chinese investments, it is worth mentioning the acquisition in July 2012 by Golden Millennium Group (GMG), a Singapore-based subsidiary of SINOCHEM, of 35 per cent shares of the Belgium holding SIAT (Société d'Inves-

Table 3: Distribution of Gabon's FDI inward stock, 2003-2012 (Million US Dollars)

\begin{tabular}{|c|c|c|c|c|}
\hline \multirow{2}{*}{ Year } & Total FDI & \multicolumn{3}{|c|}{ Partner Country } \\
\cline { 3 - 5 } & Inward Stock & France & US & China \\
\hline $\mathbf{2 0 0 3}$ & -73 & 1,782 & 370 & 24 \\
\hline $\mathbf{2 0 0 4}$ & 246 & 2,163 & 483 & 31 \\
\hline $\mathbf{2 0 0 5}$ & 488 & 2,219 & 121 & 35 \\
\hline $\mathbf{2 0 0 6}$ & 756 & 2,638 & 113 & 51 \\
\hline $\mathbf{2 0 0 7}$ & 1,026 & 2,856 & 249 & 56 \\
\hline $\mathbf{2 0 0 8}$ & 1,799 & 1,482 & -87 & 88 \\
\hline $\mathbf{2 0 0 9}$ & 2,372 & 1,944 & -78 & 100 \\
\hline $\mathbf{2 0 1 0}$ & 2,871 & 1,935 & 586 & 125 \\
\hline $\mathbf{2 0 1 1}$ & 3,567 & 1,731 & 63 & 127 \\
\hline $\mathbf{2 0 1 2}$ & 4,269 & 1,780 & 157 & 128 \\
\hline
\end{tabular}

Sources: OECD Stat, 2014; China Commerce Yearbook 2013, China Commerce and Trade Press; UN Comtrade Database, 2013; World Trade Organization Trade Profiles, from 2006 to 2013. 
Table 4: Distribution of Gabon's FDI Inflows, 2003-2012 (Million US Dollars)

Table 4: Distribution of Gabon's FDI Inflows, 2003-2012 (Million US Dollars)

\begin{tabular}{|c|c|c|c|c|}
\hline \multirow{2}{*}{ Year } & \multirow{2}{*}{$\begin{array}{c}\text { Total FDI } \\
\text { Inflows }\end{array}$} & \multicolumn{3}{|c|}{ Partner country } \\
\cline { 2 - 5 } & 206 & France & US & China \\
\hline $\mathbf{2 0 0 3}$ & 320 & -33 & 11 & \\
\hline $\mathbf{2 0 0 4}$ & 242 & 42 & 61 & 6 \\
\hline $\mathbf{2 0 0 5}$ & 268 & 138 & -166 & 2 \\
\hline $\mathbf{2 0 0 6}$ & 269 & 158 & -17 & 3 \\
\hline $\mathbf{2 0 0 7}$ & 773 & 275 & 130 & 32 \\
\hline $\mathbf{2 0 0 8}$ & 573 & 382 & -439 & 23 \\
\hline $\mathbf{2 0 0 9}$ & 499 & 54 & 4 & 2 \\
\hline $\mathbf{2 0 1 0}$ & 696 & -8 & 327 & 31 \\
\hline $\mathbf{2 0 1 1}$ & 702 & 26 & 94 & 78 \\
\hline $\mathbf{2 0 1 2}$ & 207 & & 23 \\
\hline
\end{tabular}

Sources: OECD Stat, 2014; China Commerce Yearbook 2013, China Commerce and Trade Press; UN Comtrade Database, 2013; World Trade Organization Trade Profiles, from 2006 to 2013.

tissement pour l'Agriculture Tropicale or Tropical Agriculture Investment Company). SIAT's subsidiary, SIAT Gabon, created in 2004, is Gabon's leading producer of palm oil and natural rubber (SIAT 2012). SIAT Gabon is active in three provinces (Moyen Ogooué, Estuaire and Woleu-Ntem) and produces among other things cooking oil and soaps. SIAT is also active in Nigeria and Ghana in the same sectors while GMG is already present in Cameroon and Cote d'Ivoire (Ballong, 2012). Presented as a "strategic alliance", this investment may be indicative of a stronger Chinese willingness to be more active in the Gabonese agro-industrial sector (SIAT Gabon). In Gabon, SIAT's main competitor is Olam, an Indian group based in Singapore, whose production areas include timber, rubber, palm oil and fertilisers. In January 2014, Olam sold a large part of its forestry and saw milling assets to a consortium of Chinese investors, for US\$ 18 million (Chan, 2014). All in all, while Gabon is not a privileged destination for Chinese FDIs in Africa, in view of its small population, it is hard to argue that it has been neglected either. 
AFRICAN

AFFAIRS

\section{China's infrastructure projects in Gabon}

Apart from the projects already mentioned as the Poubara Dam, China has been involved in a growing number of infrastructure projects, especially the construction of roads and the iconic Port Mode in Libreville. Both types of project have a strong political dimension.

In September 2013, the China Road and Bridge Company signed a contract to build the road from Port-Gentil to Libreville via Omboué and then Lambarene. Planned over a period of four years, this ambitious and difficult project (it crosses a very swampy region) will for the first time link up Gabon's second city and the heart of its oil production to its capital. Today one can only reach Port-Gentil, located on the Mandji island, from Libreville by boat or by plane. This project will cost 341.837 billion CFA (US\$ 723 million), mainly financed by China's Eximbank (95 per cent) and symbolically by the Gabonese government ( 5 per cent).

The construction of the first section (Port-Gentil-Omboué, $93 \mathrm{~km}$ ) was started in November 2013, with Gabon having received a concessional loan from China of 64.8 billion CFA (US\$ 137 million) to finance it ${ }^{6}$. The extension from Omboué to Yombi $(243 \mathrm{~km})$ will eventually allow this road to link up with the Nationale No. 1, Gabon's main road from Libreville to the south of the country (Lambaréné, Ndendé) and Congo-Brazzaville. It has been reported that this big construction project will create 2,000 jobs for the Gabonese and 800 for the Chinese (Ogandaga, 2013).

The road project has clear political implications since the region of Port-Gentil was for a long time an opposition stronghold to Omar Bongo. For instance, some violence took place there against electoral fraud in 2009 (the French consulate was burnt down). Although since then, the ruling Parti Démocratique Gabonais (PDG) has been able to have its candidate elected mayor of the city, Ali Bongo is clearly trying to reach out to Ogooué's Maritime voters, with the help of Chinese money.

The Port Môle project in Libreville is an interesting case of Chinese opaque cooperation serving obvious political purpose as well. Announced on the occasion of 
the "New York Forum Africa" in June 2013 ${ }^{7}$, Port Môle is an ambitious project that will create a window of "emerging Gabon" on reclaimed land located outside of the Boulevard de l'Indépendance, the capital's main (and often congested) north -south road along the seaside, and in front of the Boulevard Triomphal that leads to the ministries and the National Assembly. The project will include commercial, cultural and conference centres, a museum, hotels, offices and a cruise terminal. It is supposed to become the new heart of Libreville. The overall budget of this project amounts to US\$ 450 million; signed in May 2012 with the China Harbour Engineering Company (CHEC) for maritime infrastructure. The contract includes the creation, in 360 days, of a reclaimed peninsula of 43 hectares and should cost US $\$ 120$ million, reimbursed over 20 years, probably with a grace period that was however not made public (ANGT, 2013; Chine-Gabon, 2013).

Officially a tender was organised, but no one in the construction industry saw the actual tender (Interview 2, January 2014). It appears that the Chinese company was handpicked by the president because of the urgency of the project; it must be finished in 2015, or one year before the next presidential election. For the same reasons, the Gabonese government has allowed the Chinese contractor to rely to a large extent on a Chinese workforce and has not been very vigilant about the consequences for the Libreville estuary of CHEC's dredging operations (Interview 2, January 2014).

\section{Other Chinese economic inroads}

Chinese companies have made some inroads into other economic sectors like the telecoms where Huawei and ZTE's arrivals have been seen as the main drivers for French giant Alcatel's departure. However, the local market remains dominated by other actors: Gabon Telecom is owned by Maroc (Morocco) Telecom while the main operator is Airtel, controlled by an Indian company. And there have been cases of co-operation between Chinese and Western companies in this sector (for example between Huawei and French company Bouygues for the installation of backbone optic fibres). In other words, this sector has remained very open and diverse (Interviews 2 and 6, January 2014). 


\section{AFRICAN \\ EAST-ASIAN \\ AFFAIRS

In the wholesale distribution and supermarket sectors, more Chinese merchants now compete with the well-established French companies (for instance Casino) or Lebanese traders. Chinese merchants are sometimes accused of not respecting the customs legislation but similar criticism has been made against other operators, especially the Lebanese.

Chinese presence in the fishing industry must be indicated since it has created some frictions with the local authorities and fishermen, for instance in Mayumba (Gabon: Pêche Sauvage, 2012). A growing number of Chinese fishing boats even fish for Gabonese companies and market. Although legally forbidden, the Gabonese ministry of Agriculture and Fisheries seems to tolerate this practice and has been accused by some of our interviewees of corruption. In the last few years, Chinese boats have focused on shrimp fishing with an intensity that has alarmed the Gabonese presidency which wanted to ban shrimp fishing altogether in early 2014. In any event, with the help of the EU and on the basis of conventions concluded between the EU and Gabon, French and Spanish tuna fishing boats have been asked to exert a surveillance of fishing activities in Gabon and report illegal fishing. This measure is understood as mainly targeting Chinese fishing boats (Interview 4, January 2014).

In the service sector, it is worth mentioning the successful emergence of the Chinese company "Groupe l'Etoile d'or" which has built and is managing several mid -range hotels (three stars) in Libreville, especially in the districts of La Sablière, Louis, London, Quaben and Montagne Sainte. Filling up an underdeveloped market niche, these hotels are popular not only among Chinese delegations but a growing number of foreign visitors who cannot afford the often overpriced and illmanaged five stars hotels of the capital.

The development of Sino-Gabonese co-operation since the mid-2000s has also led to the opening of a growing number of Chinese restaurants and shops, particularly in the animated district of Louis.

\section{A small but dynamic Chinese community}

The Chinese community in Gabon is still very small but dynamic and growing. As 
usual, estimations vary. For the Chinese embassy (Interview 5, January 2014), their number is around 2000 to 3,000, not much more than in 2007 (Centre for Chinese Studies, 2007: 89). While the vox populi gives figures ten times larger (20,000 to 30,000). More cautious sources indicate that they are 6,000 Chinese nationals, probably half of them not registered, concurring with the official data (Interview 3, January 2014). Most Chinese $(2,000)$ work on projects and are not destined to stay permanently in Gabon while long-term Chinese resident do not number more than 1,000 (Interview 5, January 2014).

The local Association of Overseas Chinese in Gabon includes only 2,000 members and the number of Chinese businesses in Libreville is estimated at 20-30. The Gabonese authorities do not see Chinese immigration as an issue as it has remained very difficult for Chinese migrants or contractual workers who wish to stay behind to get a residence permit. The powerful Direction générale de la Documentation et de l'Immigration (General Office of Documentation and Immigration) of the Ministry of Interior is very restrictive and appears much harder to be bribed than its counterparts in the neighbouring countries (Interview 2, January 2014).

\section{Other areas of co-operation}

\section{Educational co-operation}

The education co-operation between China and Gabon has remained largely symbolic. The number of scholarships for Gabonese students to study in China is still fairly low - with about 40 scholarships per year (Interview 5, January 2014), although it has increased since 2010. The total number of Gabonese students in China was 215 in 2008 and probably around 300 in 2012.

Today, most Gabonese students continue to study in France. In 2010, 4,205 of the 5,793 Gabonese students in "international mobility" went to France (73 per cent) ${ }^{8}$. In addition, there have been some talks since 2006 about the opening of a Confucius Institute at the Omar Bongo University in Libreville but in 2014, it was not yet open, for unknown reasons, underscoring a lack of enthusiasm on the Gabonese side. One should add to this the fact that most Gabonese from well-off fami- 
lies do not go to the university in their own country but overseas, mainly in France but also increasingly in the USA. Moreover, Ali Bongo's priority is not Chinese but English which in 2012 became Gabon's second official language, underscoring a willingness not only to develop closer relations with the USA but also to enhance regional integration with Anglophone neighbours.

\section{Military exchanges}

Here again, owing to the Gabonese armed forces' very close relationship with France and the presence of a permanent French military base near Libreville (1,600 marines), it has been hard for China to develop a meaningful military cooperation with Gabon. Military exchanges between Libreville and Beijing have remained very secretive, carefully but discreetly observed both by Paris and Washington. Yet, in 2007, a military attaché joined the Chinese embassy, underlining the growing strategic importance for China of Gabon as far as Central Africa's regional security is concerned, both because of the presence of France's major permanent military basis in Central Africa but also the USA's interest in Gabon. Around 2008, there apparently were speculations about the opening of an Africom base in Gabon (Wikileaks, 2008). The involvement of French troops stationed in Libreville in the stabilisation of the Central African Republic (CAR) in 2013-2014 has confirmed the usefulness for China or any great power to have a military intelligence officer there. It can be added that, due to its stability, the Chinese government has chosen Gabon as a gathering place, if the outbreak of trouble or violence in CAR, Cameroon or elsewhere requires the evacuation of its nationals from Central Africa.

For these reasons probably, military exchanges between Gabon and China have increased in the last few years. In June 2009, both armies conducted a joint humanitarian medical urgency exercise, the first of this kind organized with an African military (PLA Daily, 2009). In October 2011, Gabon's Defence Minister Bokemu Ongzongka visited China and in June 2012, the PLA deputy chief of staff Sun Jianguo visited Gabon (Ambassade de la République populaire de Chine au Gabon, 2012). Although these exchanges and visits are part of what China calls its 
"military diplomacy", they have allowed some Gabonese officers to be invited for a few months to the National Defence University in Beijing and may convince Libreville, in spite of French objections, to buy a limited number of cheaper military equipment (such as transportation vehicles) from Beijing in the future.

\section{Limits of China's presence in Gabon}

However, China's presence and influence in Gabon has witnessed several hurdles. First, some of its companies and industrial projects, particularly Addax and Bélinga, have failed. Secondly, the Gabonese government and society have accumulated a number of grievances that, while not very different from elsewhere in Africa, underscore the difficulties and slowness of Chinese authorities, and more particularly, companies' adjustments.

\section{The Addax affair}

China had earlier encountered some difficulties in Gabon's oil industry. In 2006, Unipec, a subsidiary of Sinopec, was accused by local NGOs and the World Bank of exploring oil in the Loango National Park, damaging the environment, especially the forest of this protected area. However, most analysts agreed that the responsibility of the dispute around this exploration block (called the Lotus block) was shared by the Chinese company, which had committed obvious negligence, cutting down many trees, and the Gabonese government which had given Unipec the right to explore oil in Gabon. The failure on Gabon's side was the result of a lack of coordination between the Oil Ministry and the Forestry and Environment Ministry of Gabon (Centre for Chinese studies, 2007: 95-96). In spite of the bad image that it created, particularly among Gabonese NGO activists, a settlement was reached after a few months of negotiations between Unipec and the Gabonese government (Alves, 2008:15-16).

The Addax affair which broke out in late 2012 was more serious. Initially a Canadian firm, then Americo-Swiss and Addax Petroleum was finally acquired by Sinopec in 2009. After this acquisition Addax Petroleum was accused by the Gabonese government of bad management, damage to the environment, corruption and 
tax evasion and more generally having failed to fulfil its contractual obligations. As a result, Addax lost the right to exploit one of five fields it had in Gabon, the Obangue field, transferring it to the newly created state-owned Gabon Oil Company (GOC). Negotiations having failed, Sinopec decided to sue the Gabonese government before the Paris-based international Chamber of Commerce's arbitration court but lost its case in September 2013 (Farge, 2013). Negotiations have been held since then and a new ten-year production sharing contract was signed by Addax and the Gabonese Republic in January 2014, but only on three fields, including Obangue (Addax, 2014). It was later revealed that Addax paid US\$ 400 million in compensation to the Gabonese Oil Ministry, under Etienne Ngoubo, due to an estimated loss to Gabon of US\$ 1 billion (Agence Ecofin, 2014). How had this happened?

China is not a big player in the Gabonese oil industry. But by acquiring Addax in 2009, Sinopec wished to enter the country's oil producers club. In 2012, Addax was Gabon's fourth largest oil producer (23,000 barrels per day) far behind Shell (64,000 b/d), Total (57,000 b/d) and Perenco (55,000 b/d). In oil exploration, China is not a major actor either, only two of the ten companies involved are Chinese: Sino Gabon Oil and Gas and Sinopec Overseas (Trésor, 2012) ${ }^{9}$.

With regard to the dispute, the official reasons for calling the dispute as presented by the Gabonese government are only part of the truth. Environmental degradation had been evidenced by outside witnesses before and Addax was openly threatened with having one of its remaining fields closed "if the situation did not improve". However, the main accusation was tax evasion. Addax was targeted for having reported underestimated production results, as a result avoiding paying some US\$ 400 million of royalties to the Gabonese treasury (Interview 2, January 2014). This discovery was the consequence of an audit of all oil companies launched by the Gabonese president with the help of an US audit firm in 2011-2012 (Farge, 2013). All companies, including Total and Shell, were criticised and asked to make some adjustment but Addax was singled out because of the magnitude of its fraud and the multiplicity of its bad practices. Of course, some observers have noticed that it was hard for the Gabonese government to be too harsh towards companies in 
which it has a share ( 30 per cent in Total, less in Shell). But, this audit has been part of Ali Bongo's policy of enhancing accountability in the oil industry and did not particularly target China (Interviews 2 and 7, January 2014).

Having said that, the Addax affair revealed two trends: 1) the tendency of big Chinese state-owned companies operating in Africa to take more liberty with the rules of the game than their competitors, not only in the oil business; 2) the increasing vigilance of the Gabonese government and its inclination to use US firms and experts to help them in correcting bad practices.

\section{The Bélinga fiasco}

China's second major setback in Gabon was the decision made by the Gabonese government in December 2013 to cancel the license that had been given to COMIBEL to exploit the Bélinga iron ore mine. COMIBEL (Compagnie minière de Bélinga), in which the CMEC held 75 per cent of the shares after 2007, was reimbursed US\$ 34 million for the feasibility study that it had completed but the mine was again open to any company willing to invest in the costly but potentially highly profitable project.

Omar Bongo had invested a lot of political capital, and calculation in this project. He also expected a lot of returns in terms of modernisation and job creation from the CMEC deal, hoping to turn Bélinga into Gabon's second city (Yates 2008: 218). China's expectations were not smaller; Bélinga then being presented as its "crown jewel" in Gabon, and part of a larger plan to enhance not only its economic but also political influence in Gabon (Alves, 2008: 20; Dittgen, 2011a: 11). So why did it fail?

As usual, many factors played a role in this fiasco but three were clearly more influential (Interviews 2, 4, 5, 9, January 2014): 1) CMEC's inability to pilot and coordinate such an ambitious and complicated infrastructure-for-minerals-barter deal; 2) the increasing criticism of the Gabonese NGOs and the slowness of the environmental studies; and lastly 3) Omar Bongo's death and his son's decision to take advantage of the difficulties encountered by COMIBEL to change horse be- 


\section{AFRICAN \\ EAST-ASIAN \\ AFFAIRS \\ THE CHINA MONITOR}

fore it was too late. The volatility of iron ore prices may have also made the CMEC hesitant (Dittgen, 2011b: 14) but that was not presented as a decisive reason for freezing the project.

Bélinga is one of the largest untapped iron ore deposits ( 1 billion tons, for an iron ore purity of 60 per cent) in the world and stretches across Gabon, Cameroon and Congo Brazzaville territories (Trésor, 2013). However its remote location and the much needed infrastructure to be built for its exploitation (dams or other sources of electricity, railroads, and harbour) kept any project plans limited in terms of cost until demand and prices of the raw mineral began increasing in the 2000s.

The Chinese had submitted a very comprehensive and self-financed US\$ 3 billion offer. This offer included the construction of a $560 \mathrm{~km}$ new railway line in two sections (Belinga to Booue and Ntoum to Santa Clara, a port north of Libreville) due to be completed in 2009, the construction of two hydroelectric dams on the Ivindo river, including the Bélinga Dam (50 MW, cost: US\$ 754 million), and of an iron mining facility (construction cost: US\$ 790 million). It also included the creation of a deep-water mining harbour in Santa Clara that can manage 20 million tons of exports, for which the feasibility study was concluded in December 2008 (Banktrack, 2011). The construction of these infrastructure projects was supposed to start in 2008 and be complete in 2011, when the mine was due to become operational and the first shipments of iron ore to China could take place. It was then also indicated that the CMEC had "carefully chosen partners", including the Eximbank, the Panzihua Iron and Steel Company Mines, China Railway Engineer Corporation (CREC) and the China Harbor Engineer Company Ltd., a subsidiary of China Communication and Construction Company. 30,000 new jobs were due to be created including 26,000 for Gabonese citizens; training, including in China for Gabonese engineers and technicians was to be organised and the construction in Bélinga of a Steel City (cité métallurgique) was also projected. 30 million tons of iron ore per year, 90 per cent for China, was expected to be produced (International Rivers, no date).

It is hard to identify a more ambitious project, and its complexity has been often underestimated, both by the Gabonese government and the China-led consortium. 
Actually, Chinese companies are more and more reluctant to get involved, let alone lead multi-dimensional projects of such a grand scale (Interviews 5 and 10, January 2014). As its name indicates, the CMEC's main activity is trading heavy machineries and equipment, not mining nor dam, railways or harbour construction. The financing was not an issue, at least for China, as the concessional model proposed was to repay the investment with the production of the mine over a 25-year period of time (Jansson, 2009: 24). But COMIBEL's main shareholder did not have the expertise required to properly assess the magnitude of the projects and forecast the resistances that it would provoke within the Gabonese society (Interviews 2, 5 and 12, January 2014).

That brings us to the second reason of failure: the mobilisation of environmental protection NGOs against not so much the exploitation of the mine itself than the lack of benefits for the local population and the construction of a dam on the Ivindo river in the heart of Gabon's forest and national park. Among them, Brainforest, an ONG directed by Marc Ona Essangui and supported by Rainforest United Kingdom, played a leading role, proposing among other things to move the construction of the dam from the Kongou Falls to the Tsengué-Lélédi Falls, a site that was recommended by a feasibility study in the 1960s for its cost-effectiveness and greater potential benefits to local communities (Rainforest, 2009; Openshaw, 2012). Pressure was also exerted by Gabonese NGOs on their government so that it gets more involved in a project that was perceived by them as too secretive, not environmentally sustainable and that would give CMEC much more land that it needed. As a result of this lobbying, the Gabonese government's shares in the COMIBEL increased from 15 per cent to 25 per cent in December 2007.

These developments together with the global economic downturn in 2008 clearly slowed down the project and affected the CMEC's enthusiasm, pushing back any start of the exploration activities to a later date (it was initially planned to be completed by 2012). Eventually, in 2009, the Chinese operators delivered feasibility and environmental impact assessment (EIA) studies; ambassador Xue Jinwei intervening to accelerate the process. And it was reported that exploration activities were about to start when Omar Bongo died (Jansson, 2009:40). 
In any event, it rapidly appeared that this project had much less support from his son, Ali Bongo (Interviews 7, 8 and 9, January 2014). Both for electoral and diplomatic reasons Omar Bongo was ready to give China a preferential treatment and to disregard the overall cost of the project. The large interest-free or preferential loans offered by Eximbank were indeed attractive (Dittgen, 2011b:15). However, the Gabonese government had also to face growing criticism for the tax benefits enjoyed by COMIBEL, the long period of reimbursement of the Chinese loan (25 years) and the high risks attached to it, due to the fluctuations of iron ore prices and the uncertainties about the Bélinga iron ore reserves. Indeed, China's interests were very well protected in the contract, including an additional clause requiring other possible methods of compensation from the Gabonese government, should the Bélinga iron ore reserve be insufficient to reimburse the loan (Dittgen, 2011b:21). Moreover, questions were raised about the maintenance and utility of infrastructure after 25 years of operation and the fact that production was to be mainly sold to China. Finally, the overall price tag of the project was not US\$3 billion but US\$10 billion according to well-informed sources, putting on Gabon's shoulder a financial burden that would have fed its external debt and it would have difficulties to reimburse (Trésor, 2013). In other words, the Chinese package turned out to be much less attractive than it had initially appeared (Jansson, 2010).

Diplomatic considerations have also contributed to the Gabonese government's decision to cancel the concession. Closely scrutinised by the ANGT, the CMEC's difficulties gave Gabon the occasion to decrease its reliance on China for its development (Interviews 2 and 5, January 2014). While the Sino-Gabonese relationship does not seem to have been deeply affected by this cancelation, it had been Beijing's second disappointment with Libreville in a short period of time. Although, the Bélinga fiasco, and Addax's affair were not caused by the Chinese government but by some of its state-owned companies, the involvement of the former, through its embassy, in the most delicate negotiations related to these deals and eventual cancelations, contributed to feeding anti-China sentiments in Gabon.

Today, the Gabonese government is in the process of transferring the Bélinga concession to BHP (Broken Hill Proprietary) Billiton, an Australian company that will 
first organise a consultation to evaluate the size and quality of the mine as the last assessment was made in the 1960s and is thus considered to be out-dated and unreliable (Interview 2, January 2014). But the introduction in 2013 of a new Gabonese mining code may complicate the picture. And other competitors, based in Congo Brazzaville or in Cameroon, are also interested in exporting Bélinga's iron ore through other channels, including Cameroon's southern harbour of Kribi. In any event, the battle for Bélinga is far from over.

\section{Gabonese government and society's main grievances}

The Gabonese government has remained very reluctant to make public any strong grievances against China or Chinese companies. The need to keep a positive diplomatic relationship with China as an important emerging partner has clearly been the main reason of this discretion. Both sides have a vested interest in deepening their co-operation, not only to successfully complete the existing projects but to stimulate new ones.

However, while subdued, the Gabonese government has not been shy from acting in order to correct situations that it has perceived as unhealthy. In other words, the Sino-Gabonese "honey moon" is over (Interview 3, January 2014). For instance, without singling out the Chinese companies, in 2010, it imposed a strict ban on exports of unprocessed wood, putting a partial end to timber exploitation seen as unsustainable. In 2005, 80 per cent of China's timber imports from Gabon disregarded the law or were involved ub tax evasion and the bulk of wood, including 60 per cent of all okoume (a tropical wood) exports and 36 per cent of wood exports, was exported raw to China (Centre for Chinese Studies, 2007: 85-86). Although some Chinese operators' illegal practices have continued (pieces of unprocessed timber are still exported), they are better controlled globally. These changes have led to Chinese companies relocating to neighbouring countries such as Cameroon and Congo Brazzaville where log exporting and smuggling is easier (Jansson, 2010; Interviews 6, 7 and 10, January 2014).

Simultaneously, the Gabonese authorities have improved their level of transparency and governance, forcing all external actors, including the Chinese to more often 
comply with the rules. However Chinese companies prefer to continue to operate in isolation: for instance, they have refused to join the Union minière du Gabon (UMIGA, Association of Gabon's mining companies), an organisation created in 2010 that although chaired by a Frenchman working for an US company, is in close contact with the Gabonese government and shares information with companies active in this sector. This is probably for the latter reason that the Chinese companies have preferred to stay out. In order to circumvent this self-protective reaction, the Gabonese authorities have tried to associate Chinese and other foreign contractors. For example, on the Grand Poubara dam project, in order to avoid the use of counterfeit equipment, technical control and certification was attributed to a French company (Interviews 6 and 7, January 2014).

The Gabonese society and NGOs' main grievance against Chinese operators have been the level of secrecy of China-Gabon co-operation (Centre for Chinese Studies, 2007: 90). Another, nearly as important, has been damage or risk of damage to the environment of Chinese projects. As we have seen, on several occasions (oil exploration, Bélinga), local NGOs have been able to mobilise the local and foreign public opinion around this cause and force the Gabonese government to react. There are also a few tensions with the local population as well as the Lebanese community $(5,000)$ as a result of Chinese private firms moving into the formal and informal service and trade sectors (Ndong, 2013). Nevertheless, on the whole, there is much less friction between the local society and Chinese companies than in other African countries.

\section{Grievances of other economic actors (and competitors)}

Grievances expressed by China's competitors in Gabon are naturally stronger than among Gabonese officials or citizens. They particularly target Chinese companies. The Chinese embassy is usually exempted from attack even when projects are closely monitored or supported by the Chinese government. As elsewhere in Africa, China's economic competitors perceive that Chinese companies have a stronger tendency to bend the rules of the game in their advantage.

Not surprisingly, this consideration applies in particular to the use of a Chinese 
workforce in Chinese construction projects. In Gabon, the official quota in any company or project is to hire one expatriate for nine Gabonese workers. In reality, this quota is difficult to meet for reasons mentioned at the beginning of this article: the lack of well-trained and cheap technicians (Interview 5, January 2014). In addition, local workers are reluctant to work for Chinese contractors because they are usually ill paid (60,000 CFA or US\$ 125) and the work is hard ${ }^{10}$. As elsewhere, having accepted this job to save money and living a Spartan life, Chinese contractual workers work long daily shifts (10 hours) in order to complete the project, and their contract, as quickly as possible, creating tension with the local workforce (Centre for Chinese Studies, 2007: 87, 92, Interviews 6 and 10, January 2014). For these reasons, Chinese companies usually enjoy a more lenient treatment, described by many competitors as "exceptional", since in most projects, Chinese workers can represent 25 per cent to 50 per cent of the workforce in the road construction sector for instance.

Urgency has already been mentioned as an argument to wave the rules. However, this reason is rarely included in the initial contract, except perhaps in the Port Môle project where a large number of Chinese workers have been spotted (although details have not been made public). For instance, in the case of the national stadium construction project, which on paper had abided by the usual workforce quotas, the dramatic increase of Chinese workers was approved later, in order to make sure that the project was completed on time for the African Cup of Nations. Some have even accused the Chinese contractor of slowing down work on the construction of the stadium on purpose so as to be able to later impose its conditions (Interviews 6 and 7, January 2014).

Another grievance heard in Libreville is Chinese companies' unfair competition and dubious practices. For instance, in 2013-2014, disguised as imports for construction projects and consequently tax-free, Chinese cement has over-flooded the local market, putting CIMGABON, a subsidiary of the German Company Heidelberg Cement, on the verge of bankruptcy. Protests of the German embassy that has called for a respect of WTO regulations have not yet (in January 2014) put an end to this practice ${ }^{11}$. In 2013 miners of China's Jiahua Mines, which is exploring 
gold and copper in south-western Gabon, were found extracting gold on Morocco's Managem's site (The Report, 2013).

\section{Conclusion}

China has clearly become a crucial partner to Gabon, on par with the United States, the EU or even France. However, Ali Bongo has remained keen not to put all his eggs in the same basket and to use his country's other partners as a leverage to better balance and scrutinise the activities of Chinese companies. In so doing the Gabonese president seems to be adapting and reversing to some extent on his father's "blackmail diplomacy" towards France (Bayart, 1990:49; Obiang, 2007:201-60).

In Gabon, as elsewhere in Africa, China is perceived as a key diplomatic interlocutor. More importantly, it has for at least ten years been a more robust driver of economic development. Some Gabonese government officials even see China as a model for their country's modernisation (Centre for Chinese Studies, 2007: 76). Ready to take bigger risks than others in order to get access to natural resources, Chinese companies have been warmly welcomed to contribute to Gabon's industrial diversification. And in spite of some recent setbacks, Gabon-China economic co-operation will continue to deepen.

However, China's political and economic influence on Gabon should not been exaggerated. Its diplomatic contribution to solving Central Africa's regional crisis (for example in CAR) has remained marginal. Chinese actors still have a limited impact in Gabon as the oil, mining and, to a lesser extent, timber industries (in other words all the strategic sectors) are still mainly controlled by Western, and especially French companies. And China's cultural influence is negligible. While more Gabonese learn English and connect with the US, France's soft power, or what some analysts call "cultural imperialism", will continue to dominate Gabon through its language, its laws and institutions as well as its way of life, with a living standard that is exceptionally high, compared to other former French colonies (Yates, 2008:221). This is a clear impediment to China's influence and soft power in Gabon, forcing its diplomats and companies to master the French language ra- 
ther than convincing the Gabonese to learn Chinese.

In any event, Gabon's case shows that the content and the contours of any African country's partnership with China depends upon itself, its own political vision, its ability to choose and its capacity to well manage the co-operation projects that both sides have agreed upon to launch and implement.

\section{Endnotes}

1. The M'Bembelé manganese mine's reserves are estimated at 26 million tons (out of a total for Gabon of 200 million tons); in 2013, it produced 280,000 tons; production should gradually increase to 1 million tons and last for 30 years (Trésor, 2013); the CICMH has 340 workers including 255 Gabonese (75 per cent) and 85 Chinese (25 per cent); in 2013, COMILOG which French ERAMET is the main stakeholder ( 63.7 per cent) produced 4 million tons manganese. The mineral purity of the M'Bembelé mine is 30-40 per cent, considerably lower than in Moanda, exploited by COMILOG. http://infosgabon.com/?p=3417 22 October 2010. (Interview 11)

2. Gabon has 6,000 MW of undeveloped hydro potential; hydropower provides 75 per cent of Gabon electricity.

3. However, during that trip, according to some sources, the Chinese government refused to invite Ali Bongo to Beijing because of the difficulties emerging around the Bélinga project (see below, Interview 8).

4. A. Gabon's total exports and imports are quoted from the WTO Trade Profiles, while the trade volumes with US, EU, and China are author's calculation based on the percentage suggested by the WTO Trade Profiles.

B. Gabon's trade volumes with France in 2005 and 2008 are extracted from UN Comtrade Database, while their volumes in 2012 are extracted from OECD Stat. Their shares in Gabon's merchandise trade are the author's calculation based on the total exports and imports suggested by the WTO Trade Profiles.

C. In 2005, it refers to EU (25) instead of EU (27). 
AFRICAN

5. Imports from Hong Kong or which are not registered by Gabonese customs explain the difference.

6. The loan will be reimbursed in 20 years with a 7 year grace period and a 2 per cent interest rate. This first section also includes the construction of a bridge to Booué on Ogooué river. This first agreement was signed in September 2013 by the Gabonese Minister of Economy, Luc Oyoubi, and the Chinese ambassador to Gabon, Sun Jiwen (Ntoutoume 2013).

7. Launched by Ali Bongo in 2012 and meeting every year in Libreville, the New York Forum Africa sees itself as the "African Davos".

8. In 2010, France welcomed around 30 per cent $(111,195)$ of all the African students studying abroad; Malaysia was their top Asian destination country with 14,744 (or 4 per cent) of the total (Les notes de Campus France 2013).

9. Total was to overtake Shell again in 2013.

10. The minimum legal monthly salary in the Gabonese private sector has been CFA 80,000 (US\$ 170) since 2006.

11. According to some sources, in 2013, Gabon imported 400,000 tons of cement from China, for a market estimated at 600,000 tons, reducing CIMGABON's production to 200,000 tons (Interview 6).

\section{Bibliography}

Addax Petroleum. 2014. Addax Petroleum announces the signature of a new partnership with the Gabonese Republic. [Online]. Available: https:// www.addaxpetroleum.com/about-us/news/156-addax-petroleum- announces-the-signature-of-a-new-partnership-with-the-gabonese-republic [2014, January 16].

Agence Ecofin. 2014. Addax Petroleum a payé plus de 400 millions \$ de dédommagements au Gabon. [Online]. Available: http:// www.agenceecofin.com/droit-des-affaires/2801-17111-addax-petroleum-apaye-plus-de-400-millions-de-dedommagements-au-gabon [2014, 
January 28].

Agence Nationale des Grands Travaux (ANGT). 2013. Nouveau Port Môle.

[Online]. Available: http://www.angt-gabon.com/l-actualite/ actualites/22299/nouveau-port-mole [2013, July 31].

Alves, A. C. 2008. China and Gabon: A Growing Resource Partnership. China in Africa Report No. 4: The South African Institute of International Affairs, Johannesburg: 23.

Ambassade de la République populaire de Chine au Gabon. 2012. La délégation militaire chinoise conduite par le Chef d'Etat-Major Général Adjoint de l'APL SUN Jianguo effectue une visite de travail en République Gabonaise. [Online]. Available: http://ga.chineseembassy.org/fra/zxxx/ t940020.htm [2012, June 10].

Ballong, S. 2012. Agro-Industrie: Siat et GMG, un deal bien huilé. [Online]. Available: http://www.jeuneafrique.com/Article/JA2672p132-133.xml0/ [2012, April 11].

Banktrack. 2011. Dodgy Deal: Belinga Iron Ore Project, Gabon. [Online]. Available: http://www.banktrack.org/manage/ajax/ems_dodgydeals/createPDF/ belinga_iron_ore_project [2014, April 29].

Bayart, J. F. 1990. France-Afrique: la fin du pacte colonial (France-Africa : The end of the colonial pact). Politique africaine, 39: 47-53.

Belinga Dam, Gabon. [Online]. Available: http://www.internationalrivers.org/ resources/belinga-dam-gabon- 3597 [2014, April 29].

Benquet, P. 2011. La Françafrique, [Documentary Film]. Paris: Compagnie des Phares et Balises.

Cabestan, J. 2014. Personal interview 1. 6 January, Libreville.

Cabestan, J. 2014. Personal interview 2. 7 January, Libreville.

Cabestan, J. 2014. Personal interview 3. 7 January, Libreville. 
AFRICAN

EAST-ASIAN

AFFAIRS

Cabestan, J. 2014. Personal interview 4. 7 January, Libreville.

Cabestan, J. 2014. Personal interview 5. 8 January, Libreville.

Cabestan, J. 2014. Personal interview 6. 9 January, Libreville.

Cabestan, J. 2014. Personal interview 7. 9 January, Libreville.

Cabestan, J. 2014. Personal interview 8. 9 January, Libreville.

Cabestan, J. 2014. Personal interview 9. 9 January, Libreville.

Cabestan, J. 2014. Personal interview 10. 9 January, Libreville.

Cabestan, J. 2014. Personal interview 11. 10 January, Libreville.

Cabestan, J. 2014. Personal interview 12. 10 January, Libreville.

Centre for Chinese Studies. 2007. China's Engagement in Africa: Preliminary Scoping of African Case Studies. Angola, Ethiopia, Gabon, Uganda, South Africa, Zambia. Matieland: University of Stellenbosch, November.

Chan, D. 2014. Olam International to sell part of forestry assets, saw mills in Gabon to China investors. The Strait Times, 24 January.

China Commerce and Trade Press. 2013. China Commerce Yearbook, Beijing.

Chine-Gabon: Un contrat de 120 millions USD pour l'aménagement du Port-Môle de Libreville. 2013. [Online]. Available: http://www.afriquinfos.com/ articles/2013/6/16/chine-gabon-contrat-millions-pour- lamenagement-port -mole-libreville-224027.asp [2013, June 16].

Dittgen, R. 2011a. New Development Cycle through Long-term Investment? China and the Belinga Project in Gabon. EchoGeo, 17, June-August: 218 .

Dittgen, R. 2011b. To Bélinga or not to Bélinga? China's Evolving Engagement in Gabon's Mining Sector. South African Institute of International Affairs, Occasional Paper No. 98, November: 27. 
Farge, E. 2013. Reuters. Sinopec's Addax loses court ruling on Gabon oil licencedocument. [Online]. Available: http://mobile.reuters.com/article/ governmentFilingsNews/idUSL9N0FH00520130913 [2014, June 5].

Gabon: CHEC Nabs Port Mole Land Reclamation Contract. 2013. [Online]. Available: http://www.dredgingtoday.com/2013/06/04/gabon-chec-nabs -port-mole-land-reclamation-contract/ [2013, June 4].

Gabon: Pêche sauvage des chalutiers chinois au large de Mayumba. 2012.

[Online]. Available: http://www.gabonlibre.com/Gabon-Peche-sauvage-des -chalutiers-chinois-au-large-de- Mayumba_a19019.html [2012, August $13]$.

Jansson, J., Burke, C. \& Jiang, W. 2009. Chinese Companies in the Extractive Industries of Gabon \& the DRC: Perceptions of Transparency. Centre for Chinese Studies: Stellenbosch University, August 2009.

Jansson, J. 2009. Patterns of Chinese Investments, Aid and Trade in Central Africa (Cameroon, the DRC and Gabon). A briefing paper by the Centre for Chinese Studies prepared for World Wild Fund for Nature (WWF): Stellenbosch University, August 2009.

Jansson, J. 2010. Pambazuka News. Chinese Investments in Gabon's Extractive Industries. [Online]. Available: http://pambazuka.org/en/category/ africa_china/65779 [2010, July 8].

Les notes de Campus France. 2013. Hors série No. 7, June 2013. [Online]. Available: ressources.campusfrance.org/publi_institu/agence_cf $/$ notes/fr/ note_07_hs_fr.pdf

Michel, S. \& Beuret, M. 2010. La Chinafrique. Paris, Grasset: Fayard/Pluriel.

Ndong, M. 2013. GabonReview. Lebanon business: petite ethnographie des Libanais $d u$ Gabon. [Online]. Available: http://gabonreview.com/blog/ lebanon-business-petite-ethnographie-des-libanais-du-gabon/ [2013, August 8]. 
AFRICAN

Ntoutoume, L. 2013. GabonReview. Un prêt chinois de 64, 8 milliards de CFA pour la route vers Port-Gentil. [Online]. Available: http://

gabonreview.com/blog/un-pret-chinois-de-648-milliards-cfa-pour-la-routevers-port-gentil/ [2013, October 1].

Obiang, J. 2007. France-Gabon. Pratiques clientélaires et logiques d'Etat. Paris: Karthala.

OECD International direct investment database. FDI flows by partner country: France and USA. [Online]. Available: http://stats.oecd.org/Index.aspx? DataSetCode=FDI_FLOW_PARTNER [2014, March 20].

OECD International direct investment database. Total: All commodities. [Online]. Available: http://stats.oecd.org/Index.aspx? DataSetCode $=$ HS1988\# (Accessed April 5, 2014).

Ogandaga, M. 2013. Le Gabon Emergent. Le Gabon Émergent en action: Route Port-Gentil-Libreville début du chantier. [Online]. Available: http:// legabonemergent.over-blog.com/2013/10/le-gabon-Émergent-en- action-route-port-gentil-libreville-début-du-chantier.html [2013, October 9].

Openshaw, D. 2012. Minority Voices Newsroom. Gabon: Mining, Dam and Repression. [Online]. Available: http://www.minorityvoices.org/ news.php/fr/1138/gabon-mining-dams-and-repression [2014, April 14].

People's Liberation Army (PLA) Daily .2009. China-Gabon joint humanitarian medical rescue operation kicks off. [Online]. Available: www.english.chinamil.com.cn/site2/special-reports/2009- 06/22/ content_1826092.htm [2009, June 22].

SIAT. 2012. Siat entered into a partnership with the Singaporean base GMG Global Ltd $(G M G)$. [Online]. Available: http://www.siat-group.com/ news/siat-entered-into-a-partnership-with-the-singaporean- based-gmgglobal-ltd-gmg/ [2014, April 14].

SIAT Gabon. [Online]. Available: http://www.siatgabon.com/plantations/ [2014, April 14]. 
The Report: Gabon 2013, Mining and Industry: Oxford Business Group. [Online]. Available: http://www.oxfordbusinessgroup.com/news/added-potentialgoing-beyond-manganese-other-minerals [2014, April 29].

Trésor, Direction générale. 2013. Le secteur pétrolier au Gabon, Publications des services économiques, Ambassade de France au Gabon, Service économique, December 2012.

Trésor, Direction générale. 2013. Le secteur minier au Gabon, Publications des services économiques, Ambassade de France au Gabon, Service économique, July 2013.

Trouble in Belinga: An Update. 2009. [Online]. Available: http:// www.rainforestfoundationuk.org/Belinga_Update [2014, April 14].

United Nations, UN Comtrade Database. 2013. [Online]. Available: http:// comtrade.un.org/data/ [2014, April 15].

Wikileaks. 2008. Gabon: Africom Commander's Successful Visit. [Online]. Available: www.cablegatesearch.net/cable.php?id=08LIBREVILLE19 [2008, January 11].

World Investment Report. 2013. Annex Table 01 - FDI inflows, by region and economy, 1990-2012. [Online]. Available: http://unctad.org/en/pages/ DIAE/World\%20Investment\%20Report/Annex-Tables.aspx $\quad$ [2014, March 20].

World Trade Organization. Trade Profiles: 2006 - 2013. [Online]. Available: http://www.wto.org/index.htm [2014, June 5].

Yates, D. A. 1996. The Rentier State in Africa: Oil-Rent Dependency and Neocolonialism in the Republic of Gabon. Trenton \& Asmara: Africa World Press.

Yates, D. 2008 French Puppet, Chinese Strings?, in Ampiah, K. \& Naidu, S. (eds). Crouching Tiger, Hidden Dragon? China and Africa. Scottsville: University of KwaZulu-Natal Press. 208-223. 
AFRICAN

\title{
Mao's new democracy and Ghana's foreign policy change in 1983*
}

\author{
By Suweon Kim** \\ Department of Political Studies \\ University of the Western Cape, South Africa
}

\begin{abstract}
Flight Lieutenant John Rawlings took power by a coup d'état accusing the previous Limann regime of being neo-colonialist and being a slave of imperialists in 1981. When he took power, he was mainly supported by radical leftists and Ghana's foreign policy leant towards socialist countries. However, two years later the regime drastically reversed its foreign policy towards the West. The paper focuses on the foreign policy change in 1983 and takes a close look at the role of Maoism on the elite in the foreign policy change in Ghana. During the first two years of the Rawlings regime, the June Forth Movement (JFM) and the New Democratic Movement (NDM) were two main elite groups in the regime. Even though the JFM and the NDM shared the same goal of socialism, the two groups had different
\end{abstract}

*Note from the Deputy Editor: This article, although not necessarily directly China -Africa related, gives an insight into the policy environment in an African state after colonialism. The paper explores the driving mechanisms behind Ghana's foreign policy in the post-colonial era as it "switched between East and West". Although the ideas of "the West" and "the East" have lost much of their Cold War era logic, some states such as Zimbabwe have also seen a discussion, in the present day, on a "Look East" policy, in contrast to dependence on Breton Woods institutions.

**Suweon Kim is a PhD Candidate in the Department of Political Studies at the University of the Western Cape in Cape Town, South Africa. 
visions on how to reach to the goal. The JFM sought rapid socialism through attacking the rich and severing international links with imperialist countries. On the other hand, for the NDM, which was influenced by Mao's "New Democracy" as the name indicates, embracement of the rich business people and international players were on its path to the ultimate socialism. In the middle of the ideological conflicts between the two, Rawlings severed the link with the JFM whose leaders turned out to be threats to survival of the regime, and in the process the NDM emerged as the single influential power group. The NDM and Rawlings turned Ghana's foreign policy toward the West and sought for aid from the Bretton Woods institutions in 1983.

\section{Introduction}

Rawlings took power by a military coup in 1981 overthrowing the civilian Limann administration whose foreign policy was skewed towards the West. The new Foreign Minister Obed Asamoah argued that "in the past, we have tended to lean more to the Western countries and to ignore the possibilities of fruitful cooperation with the countries of the East. Now we are going to explore those possibilities" (West Africa, 1982e). However, this ostensibly non-aligned stance of the Rawlings regime did not mean that foreign policy of Ghana was also non-aligned in practice. In fact, the practice of foreign policy in the Rawlings regime was getting socialist countries close to Ghana and keeping distance from the West. The Rawlings regime redirected Ghana's foreign policy towards the Communist East as soon as Rawlings took office. America's Reagan administration was regarded as resurgent "old demons" (West Africa, 1982d) and countries in the Eastern bloc emerged as friends. Diplomatic relations were rebuilt with socialist countries such as Cuba, Libya, and Eastern Europe. Rawlings visited Libya, Nicaragua and Cuba and deported United States of America (US) diplomats from Ghana to which the US replied with a similar action and with an aid blockade on Ghana. However, two years later, the socialist-oriented foreign policy reversed drastically towards the West. The paper analyses the "politically suicidal" (Jeffries, 1990:159) foreign 
policy change of Rawlings in 1983 at the level of elite dynamics and examines the role of Mao's theory of New Democracy in the change.

\section{Theoretical Background}

Most of the colonialized countries in Africa and Asia became independent after World War II and at first ideology drove the foreign policy of the newly independent countries. At some point, however, the new states came to realise that political independence did not necessarily mean economic independence and subsequently began to redefine their foreign relations with a fresh economic perspective; this was the realisation that they could and should get more economic benefits from abroad in order to survive politically (Rothstein, 1976). In Ghana, the realisation was materialised in 1983 when Rawlings redirected Ghana's foreign policy toward the West. Until 1983, foreign economic policy of Ghana was the "second fiddle to traditional foreign policy concerns" (Boafo-Arthur, 1999:73).

Nevertheless, a far-reaching redirection of foreign policy is not an easy task for any government and is even more difficult for newly independent countries. Thus when a government steers its foreign policy towards foreign aid, there should be significant grounds to do so. It is true that foreign policy always changes to correspond to any changes in the goals of a state; after all, the term "foreign policy" means "a goal-oriented or problem-oriented program by authoritative policy makers (or their representatives) directed toward entities outside the policy maker's political jurisdiction" (Hermann, 1990:5). Far-reaching or fundamental redirections in foreign policy take place upon the replacement of an old regime by a new one with a different political philosophy. Mostly, foreign policy can be expected to be more or less stable within a regime (Moon, 1985:312).

However, foreign policy can change within an existing regime and this change is different from a foreign policy redirection that coincides with a regime change. According to Hermann (1990), there are four levels of changes depending on the significance of the change: first, adjustment changes that only affect the level of the quantity of existing foreign policy; second, programme changes that include the means of foreign policy, for example, from diplomatic negotiation to economic 
sanction; third, problem/goal changes which refer to a change in the ends of foreign policy; and fourth, international orientation changes which include a shift in alignments.

In executing such a change within a regime, a government risks its political life or legitimacy. At the domestic level, a regime's positions on political conservativeness, balance-of-payments and trade openness are central issues which identify the regime. It is same for the competing political groups. In other words, those central issues differentiate and legitimise the regime, and therefore cannot easily be altered. Foreign policy is closely linked to critical domestic policy such as political alliances or free trade agreements with strategic international partners. Because of this, it is not expected to be fundamentally redirected until the regime is replaced by a new government with different political and economic perceptions. Also, at the international level, drastic changes in foreign policy within a regime reshape the world alliance map, which can range from adjusted economic cooperation to wars between the nations affected (Hermann, 1990). The benefit from foreign aid should be big enough to offset the domestic and international risks which might result from the foreign policy change. In addition, the reasons for the change are frequently discussed and openly expressed by the political elites and also by the public, and this disclosure helps researchers to determine the underlying intention behind the foreign policy change.

Any change to foreign policy within a regime is more challenging for those who took power in an unconstitutional way than for those who were elected through legitimate procedures. Coup leaders legitimise themselves by denying the previous regime and differentiating the new regime from the toppled one. When a coup regime takes over a pro-West administration, blaming its foreign policy direction, the new military regime naturally seeks to change the direction of foreign policy to legitimise the coup through steering the foreign policy away from the West. Farreaching foreign policy changes during the tenure of the regime rarely take place since they dilute the differences from the toppled previous regime and cast doubt on the legitimacy of the principle or stance of the coup regime. 
This paper examines one of the fundamental foreign policy changes which took place within the tenure of a military regime: the foreign policy change towards the West by the socialist Rawlings regime in Ghana in 1983. In order to examine the event, the paper focuses on the elite in Ghana. According to Burton and Higley (2001:8), elite are "persons who are able, by virtue of their authoritative positions in powerful organisations and movements of whatever kind, to affect national political outcomes regularly and substantially." Elitists believe that a seemingly pluralist system of foreign policy making is an illusion and in reality, the black box is only accessible to a limited few, or in other words, elites. They criticise realists for disregarding the internal paradigm of foreign policy making which takes place in the name of the state. Mills (1956), one of the most famous proponents of elitism, described power elites in foreign policy as a higher circle of decision makers who rank above professional politicians in congress. Elitists explain that the elitist pattern of foreign policy making can be observed clearly, especially on occasions of crisis. Kennedy's entourage led the Cuban missile crisis beyond legitimate institutions and the US's power elite dropped nuclear bombs on Japan despite congressional renunciation (Allison, 1971). Even though there are other thinkers such as Lowi (1967, quoted in Zimmerman, 1973) who believe that elites involved in the foreign policy process are smaller than the power elites, the fundamental belief of elitism is common: foreign policy is a process regulated and distributed by "a polyarchy of elites" (Zimmerman, 1973:1211). Elitism is the most viable framework to account for Ghanaian foreign policy (Akokpari, 2005). According to Nugent (1995: 107), “although a PNDC minus Rawlings would certainly have been like Hamlet without the prince, his importance did not lie primarily in his involvement in the day-to-day business of government" and "the importance of Rawlings's periodic interventions in debates about economic reform, foreign policy and democratisation was largely symbolic." In practice, foreign policy in the regime was led by elites, which included Rawlings.

\section{The foreign policy change in 1983}

The history of Ghana's foreign policy can be divided into two phases: from independence to 1983 and from 1983 up to the present. In the first phase, the locomo- 
tive of Ghana's foreign policy was ideology. If one considers Nkrumah's serious attempts to build the political kingdom as first priority, it was inevitable for Ghana to start with a politically biased foreign policy. In addition, the nature of the regime after Nkrumah reinforced the political inclination of Ghana's foreign policy direction. Between independence in 1957 and 1981, Ghana saw eight regime changes and five of them took power unconstitutionally through military coups and counter coups. Foreign policy of a regime was always counter to the policy of the previous regime. Politically loaded foreign policy redirection was unavoidable is order to establish legitimacy of a military coup regime. When Nkrumah, the first prime minister and president of independent Ghana and his Convention People's Party (CPP), was toppled by the National Liberation Council (NCL) by a military coup, the NCL and the successive regime of the Progress Party (PP) turned the course of foreign policy towards being pro-West ${ }^{1}$. However, when the PP regime was violently replaced by the National Redemption Council (NRC) in 1972, the pro-West ideology became something to destroy and so that foreign policy was readjusted to the new demand of the new military regime. The NRC was toppled by a military coup by Rawlings's Armed Forces Revolutionary Council (AFRC) in 1979, but the socialist Rawlings regime gave way to pro-West Hila Limann's People's National Party (PNP) through election. The PNP tried to win support back from the West through redirected foreign policy which was lost during the short-lived AFRC period. The AFRC was in power for three months from June to September 1979. Despite its short period in office, the AFRC sent strong anti-capitalist signals. Besides the domestic instability in elite politics, the irresistible dynamics of the Cold War exacerbated the ideological swings in Ghanaian foreign policy.

The second phase of Ghana's foreign policy began in 1983 with a foreign policy shift towards the West by the Rawlings regime. Since then, pragmatism instead of ideology has been pursued in an overly aggressive way as a central goal of foreign policy of Ghana. In the first two years of the Rawlings regime foreign policy was mainly driven by ideologically as in previous regimes. However, in 1983, the Provisional National Defence Council (PNDC) of Rawlings redirected its foreign pol- 
icy and turned to the Bretton Woods Institutions which he initially proclaimed as a foe of the regime. Since the foreign policy change in 1983 and up until today, the main objective of foreign policy of Ghana has been pragmatism rather than ideology.

The paper examines competition of two elite groups with a different leftist ideology around the time of foreign policy change in Ghana. However, it should not be translated as the diversity in the political ideology or that the competition was the only contributing factor to the foreign policy redirection. Basically, the foreign policy change should be understood from a global political economic context of the declining Cold War, the end of a commodity boom, the international oil crises and the emerging influence of globalisation. In addition, the regional and local environment should be taken into consideration; these include factors such as influx of more than one million expatriates from Nigeria, droughts and the consequent crop failure. In addition, not only contemporary factors but also historical factors such as a tradition of Non-alignment should be considered as well. Toye (1991) also argues that the combination of historical factors such as a defective development strategy since Nkrumah, exacerbated corruption and economic mismanagement in the 1970s, and the external shocks in the early 1980s, led Ghana to the agreement to the Economic Recovery Programme (ERP).

Taking those global and regional factors into consideration, throughout its independent history, Ghana was one of the "elite-politically unstable countries" (Fosu, 2009: 4) until Rawlings's second coup in 1981 which was also to be the last coup in Ghana. After the coup he stayed in power as a head of state for 19 years. Rawlings finished school in 1966, the year when Nkrumah was ousted and in 1967, at the age of twenty, signed up as a Flight Cadet and was promoted to Flight Lieutenant in 1978. He, like most Ghanaians, encountered the deteriorating economic conditions in the era of the Acheampong regime when he was an Air Force officer. A wage of a middle ranking military officer did not match rampant inflation and pilots had to stop practicing due to lack of fuel and flight parts. Rawlings who, by nature, expressed the "desire for action to right injustice" became involved in planning a coup to overthrow the corrupted Acheampong regime as did many other 
middle-rankers around that time (Shillington, 1992:37). Finally, in 1979, he led his first but abortive coup. The purpose of the coup, Rawlings claimed, was to create a chance for a dialogue with top-ranking military command but this did not happen. The coup failed and he was put on trial. Rawlings was still unknown to the public but the failed coup and the following trials made him famous. During the trials, he emerged as a hero with integrity who called for the release of his men and who accepted full responsibility. Throughout the history of coups in Ghana, Ghanaians had never seen a single coup leader who claimed responsibility and pleaded impunity for his men. Failed coup leaders were busy blaming others to save their own lives. Rawlings, on the other hand, was different in the eyes of the Ghanaians and his charisma captured the imagination of Ghanaian people (Brydon \& Legge, 1996:13).

Backed by his fame and popularity, he easily overthrew the Acheampong regime in his second attempt on 4 June 1979. The Armed Forces Revolutionary Council (AFRC) was formed with fifteen middle and lower ranking military officers, chaired by Rawlings and the AFRC became a de facto apex institution. As soon as the AFRC took power, "House Cleaning" began and the AFRC executed three former Heads of State of the country, Acheampong, General A.A. Afrifa (1969) and General Fred Akuffo (1978-9) and a few top ranking military officers. A few months later, Rawlings handed over power to elected civilian president Limann of the PNP. The newly elected PNP government offered and sponsored chances of higher education abroad to members of the AFRC as an attempt to keep them at bay, but Rawlings refused to leave Ghana and instead spent his time getting involved with leftist groups in Accra such as the June Fourth Movement (JFM), the New Democratic Movement (NDM) and socialist intellectuals from the University of Ghana. During this period, Rawlings, who formerly disavowed any form of socialism on behalf of the AFRC, converted to socialist ideology (Boafo-Arthur, 2006:258). On 31 December 1981, Rawlings came back to power with another coup overthrowing the PNP. The second coup did not have significant resistance. Rather, Ghanaians welcomed his political comeback with "great hopes" that he would be more politically trained than he was after his first coup and there was "a 
well-grounded belief in Rawlings's personal sincerity and moral integrity" (Jeffries, 1982:307).

After the coup, Rawlings invited leftists such as Emmanuel Hansen, for political consultation; Hansen believed that Ghana's economic plight could not be solved within the post-colonial structure (Hansen, 1987:170). The Provisional National Defence Council (PNDC) was formed to run the country right after the coup. The PNDC replaced the Armed Forces Revolutionary Council (AFRC) which Rawlings formed in order to deal with the aftermath of the coup. It was a coalition of neo-Marxist intellectuals, left-wing student leaders, some soldiers, and militia trade unionists in Accra. Rawlings appointed himself as Chairman of the PNDC. The PNDC consisted of seven members. Four military members and three civilians were chosen by Rawlings with the aim of enlisting as broad a support base as possible. Brigadier Joseph Nunoo-Mensah was chosen to ensure the support of senior officers in the armed forces while Warrant Officer Adjei Boadi was chosen to ensure support of junior officers. Sergeant Alolga Akata-Pore would represent core junta members. Amartey Kwei was a labour leader for the urban working class and Chris Atim was a former student leader for the young while Father Damuah represented the petty bourgeoisie. The PNDC was the highest policy-making body in Ghana, combining both executive and legislative functions. On the other hand, after Rawlings took office, political opponents were divided between the liberal New Patriotic Party (NPP) and the fragmented Nkumahist. Rawlings did not have to deal with opposing political groups who were able to call for an alternative or a transition (Levitsky \& Way, 2010:301).

Even though there were seven members from various sectors, Ghana's de facto political elite in the PNDC were divided broadly into two factions: the June Fourth Movement (JFM) and the New Democratic Movement (NDM) ${ }^{2}$. The JFM was a militant leftist group inspired by the Cuban revolution. It was formed in 1979 with the purpose of watching over the new civilian government of Limann and protecting the "gains" of the June Fourth Revolution, which was the first successful coup of Rawlings (Hansen, 1987:186). Scientific socialism of the JFM had its goal at rapid socialism by attacking the rich and severing international links from imperi- 
alist systems (Agyeman-Duah, 1987:629). The JFM was passionately opposed to any forms of collaboration with the capitalist Western countries and entities. Notwithstanding the handful of militant leftist students who founded the organisation, the JFM became a major political group once Rawlings accepted its Chairmanship. For Rawlings, who did not have a particular political base, it was an opportune position as well. As a result, when Rawlings took power through the second successful coup, the JFM regarded this as its own political success and regarded itself as the PNDC government (Hansen, 1987:186).

The dynamics between the JFM and the NDM, as two pillars of the Ghanaian elite, played a critical role in the foreign policy change. The NDM was also formed by leftist intellectuals in the University of Ghana around 1980 (Oquaye, 2004:306). A number of influential economists and scholars such as Dr. Emmanuel Hansen and Dr. Kwesi Botchwey were included together with Kwamena Ahwoi, Tsatsu Tsikata, Fui Tsikata and Asiedu Yirenkyi.

Even though most members of the JFM and the NDM were lecturers, students, or ex-students in University of Ghana, there was a critical difference between the two groups. The idea and strategy of the NDM, as its name indicates, was significantly influenced by Mao's theory of New Democracy (Jeffries, 1990:162). To elites in the NDM, socialism was an ultimate goal which was possible via the intermediary means of alliance between classes. As "the Bloc of Four Classes" in the New Democratic order, the elite in the NDM argued that not only peasants and proletariats but also petit bourgeoisies and national bourgeoisies should be entailed in the time-taking journey toward the ultimate fuller socialism and toward sounder economy. It was an approach denying a blind acceptance of Marx-Leninism and the NDM continued to exert greater influence on economic policies than the JFM did (Biswal, 1992:200-201). Moderates in the NDM asserted that co-operation with the west was necessary for Ghana to get out of the economic plight, as long as Ghanaians recognise the evils of capitalism. The dynamics between the JFM and the NDM, as two pillars of the Ghanaian elite, played a critical role in the foreign policy change. 
Foreign relations in the Rawlings regime did not start smoothly, especially with Western countries. When Rawlings succeeded in his first coup in 1979, he executed a number of former heads of states in public in the name of House Cleaning. These episodes led to a bad reputation for that regime and extremely negative responses from Western countries and neighbouring African countries. The United Kingdom (UK) was the first country that condemned the House Cleaning as "an odious mix of secret trails and public executions", and most Western countries including the US, France, Canada, and Germany warned Rawlings that economic sanctions could be imposed if further executions took place (Okeke, 1982:55-56). In addition, the neighbouring countries, Upper Volta, Togo, and the Ivory Coast also raised their concerns. Upper Volta placed a food embargo, cutting the meat supply to Ghana and Nigeria stopped the oil supply. Shehu Shagari, the President of Nigeria, had a close friendship with Ghana's Limann who was overthrown by Rawlings. However, Shehu Shagari was later also overthrown by military coup by General Muhammadu Buhari on 31 December 1983. The two newly military leaders in Ghana and Nigeria came to share similar perspectives and have close relations with each other (Okeke, 1982:55-56). Nevertheless, after the second coup, Ghana's foreign policy theme under the new Rawlings regime remained consistent regarding commitment to the Organisation of African Unity (OAU) and support to the African National Congress (ANC) and South West People's Organisation (SWAPO), even though Ghana's foreign policy toward African countries or entities was not at a top priority in the minds of the ruling elite in Ghana (BoafoArthur, 1993:136-7).

The most significant change to Ghanaian foreign policy was turning to the Eastern bloc and away from the West. In his second public speech after the coup on 2 January 1982, Rawlings announced that Ghana's foreign policy would be "nonaligned" and the regime sought "friendship and co-operation with all countries regardless of ideology" (West Africa, 1982a). However his nominal nonalignment or neutrality meant leaning toward the Eastern bloc in practice ${ }^{3}$. Even though Rawlings never claimed explicitly that he was a socialist, his regime began by claiming to be socialist oriented. This orientation came from his supporting 
base. As mentioned above, initially, leftist thinkers in the University of Ghana were key advisers to the regime. Hence, it was just a matter of time before the military PNDC restored diplomatic relations with radical countries, once it took office from pro-West PNP government. The diplomatic tie with Gadhafi's Libya, which had been severed by the PNP, was immediately restored and new diplomatic missions were opened in Cuba and Bulgaria while the Ghanaian government was closing down twelve other diplomatic missions due to budget constraints. The PNDC expanded diplomatic relations with the former German Democratic Republic, Ethiopia, China, Mozambique, Nicaragua, and Romania. This expansion was not only in the political field but also economically and culturally; a revolutionary cadre was sent for military training to Eastern European countries and Cuba (Boafo-Arthur, 1999:81-86).

However, Ghana's economic situation was not favouring the ideological courtship with international comrades. Socio-economic hazards shook the political stability. Rawlings toppled the previous civilian regime citing their economic inaction and so he needed to show results promptly to regain lost popularity. Ghana needed money and macro-economic constraints were felt harshly in the everyday life of Ghanaians. Indeed, hunger became part of daily life. Half of the urban population and two thirds in the rural areas lived below the poverty line. In 1983, income per capita, hit the lowest point in the history of independent Ghana at US\$ 185 (World Bank, 2013). In 1983, the worst droughts in Ghanaian history aggravated the situation (Fuso \& Aryeetey, 2008). Food production was severely affected and increased the demand for food imports. Basic items such as bread and sugar disappeared from markets and the government did not have money to pay its employees. Some state-owned factory workers were offered factory products for payment (Shillington, 1992:73). Moreover, Nigeria expelled approximately 1.2 million Ghanaians in the midst of the worst economic situation in Ghana. This meant that the government had to deal with an influx of equal to a 10 per cent increase in the population adding additional stress to the job market.

Rawlings was discontented with the economic situation and took the office with a strong leftist rhetoric. However, it did not take long for him to understand the 
global economic impact on Ghana's economic situation (Antwi-Danso, 2013) ${ }^{4}$. The economic situation that the PNDC inherited was "acute economic insolvency" (Jeffries, 1990:163). When Rawlings took power, inflation had been as high as 150 per cent in the two previous years and foreign debt had reached US\$ 1.6 billion (West Africa, 1982c). Concerns existed from the beginning of the coup about the record low level of foreign reserves and the high probability that international aid institutes could withdraw aid. Just after the coup, the Rawlings regime wishfully announced that "none of the countries and agencies which have been offering aid to Ghana over the past two years will be so foolish as to draw back now" (West Africa, 1982b). However, the regime clearly did not have a developmental strategy for Ghana's already struggling economy. After the six months of an ad hoc and punitive economic policy of Rawlings's regime, the situation became worse, and "there was no money even to print money" (Hansen, 1987:192).

Leftist Ghanaian elite, feeling threatened both economically and politically, flew to Eastern Europe, Cuba, and the Soviet Union. However, the international Communist comrades were embroiled in their own domestic troubles and the world was heading to the end of the Cold War. Ghanaian diplomatic missions who flew to the Soviet Union to get financial support came back empty-handed but with advice that Ghana would be better off seeking help from the International Monetary Fund (IMF). Rawlings and the PNDC needed money to maintain political power and to resolve unprecedented economic challenges in Ghana but the Eastern comrades proved to be unavailable. In addition, the Ghanaian elite were witnessing another change. Socialist African countries, such as Tanzania and Guinea were going through economic inactivity. Capitalist African countries such as Kenya and Ivory Coast, on the other hand, seemed to be growing prosperous. Now, "the most appealing option" left for Rawlings was to turn to the IMF, the formerly claimed neo-colonialist (Boafo-Arthur, 1999:83). As there was no other obvious option, a Ghanaian writer argues that foreign policy change in 1983 was imposed rather than chosen (Antwi-Danso, 2013$)^{5}$. However, a closer look at the process of negotiation discloses that Ghana's foreign economic policy in 1983 was indeed a chosen direction by the Rawlings regime rather than being imposed. 
Even though Ghana came under the personal rule of Rawlings in 1979, in the beginning he was neither an active autocrat nor a single-handed captain. Rather, at the initial stage, he was "a figurehead to lend legitimacy" to the leftists' rule since he was popular enough with civilians and the army to maintain political stability (Jeffries, 1990:159). In this early stage, the power of his supporting groups was stronger than that of Rawlings. Hence, the populist Rawlings regime had to adopt policies which could please its leftist power base. However, the left wing, mainly the JFM, soon emerged as his main rival for political power. Hutchful $(2002$, p.43) points out that even in the beginning, leftists were not Rawlings' voluntary choice and "it would be more accurate to say that it was the Right that rejected Rawlings rather than the other way around". Despite his initial weak stance, Rawlings was a good politician insofar as he could make good use of the one party to check and compete against another. Ghana's critical juncture of foreign policy change toward the IMF and the World Bank should be understood in the context of Rawlings securing a tighter grip on the Ghanaian political arena by manipulating the elite dynamics of two leftist groups of the JFM and the NDM.

When the Rawlings government embarked on secret talks with the IMF behind the back of political left, the JFM and the NDM were sceptical about the new foreign economic policy. Instead, the secretaries of the JFN and NDM suggested a leftist version of developmental strategy. The core idea of the suggestion was "autonomous and self-reliant development based on mass mobilisation (emphasis added)" (Hansen, 1987:198). However, this united suggestion was abandoned in following political manipulation and breakdown of the leftist union. In order to change foreign policy toward the IMF and secure aid from them, Rawlings needed to break down the dominant socialist alliance, Rawlings manipulated the NMD to undermine the JFM. The JFM, whose chairpersonship Rawlings once enjoyed turned out to be the biggest threat to Rawlings. Between October and November 1982, a number of incidents took place that brought JFM to an end. After an abortive coup on 23 November, a number of critical figures from the JFM were arrested. Chris Atim went into self-imposed exile after his resignation as co-ordinator of the National Defence Committees (NDCs), which gave the already ailing JFM a 
severe blow.

In order to understand the check and balance tactic by Rawlings between the JFM and the NDM, it is necessary to understand the role of the Defence Committee (DCs). The DCs were consisted of the Workers' Defence Committees (WDCs) and the People's Defence Committees (PDCs). The WDCs were set up in workplaces such as mines and factories, and the PDCs were set up in residential areas in villages and towns. As a higher organ which coordinated the activities of the PDCs and WDCs, the National Defence Committee (NDCs) was formed with a self-appointed head of Rawlings. The Interim National Coordinating Committee (INCC) was the organ preceding the National Committee. However the INCC (headed by Chris Bukari Atim, a member of the PNDC) did not operate effectively because of political checks, conflicts between groups over ideologies, and various suspicions; it changed to the National Defence Committee (NDC) in July 1982.

The ultimate task of the NDC was "to educate the nation on the objectives of the revolution" (Bing, 1984:98). The NDC issued the National Defence Committee Guidelines for the formation and functioning of the Peoples Defence Committee in 1983, in which neo-colonialism was strongly censured for the economic plight of Ghana. According to the Guidelines between 40 and 100 people are needed to set up a DC. Its functions entail: data collection on population, economic activities, and infrastructure; ensuring maximum production and storage for self-sufficient and efficient marketing; establishment of People's Shops ${ }^{6}$; education and training for raising political awareness; health and sanitation; village layout and housing; afforestation; and, defence and security. The DCs had to finance themselves and the members had to pay dues for this purpose. The DCs were designed as "the institutions through which their collective energies could be mobilised and channelled into social action in accordance with the dynamics of the transformation process" (Hansen, 1987:178).

In short, in the beginning the DCs were an influential structure that could mobilise the masses, and the elite in the JFM were occupying most key posts in the NDCs, a top organisation in charge of the whole DCs structure. The elite in the NDM 
hardly liked this and indeed they always kept their eyes on the posts in the NDCs. After the core elite in the JFM were expelled from the NDCs, Rawlings approached the elite in the NDM with a bait of newly available positions in the NDCs, and they seized the chance. Throughout this procedure the NDM turned in favour of the new foreign economic policy towards the IMF. Based on the ideology of the NDC, in the beginning, when the deal with the IMF began to materialise, the Rawlings regime pronounced that the pro-West redirection of the foreign policy was a procedural means to reach Socialist ends. Ghana's engagement with the IMF was proclaimed as an immediate expedient to achieve the ultimate goal of "complete disengagement of the country's economy from the exploitative capitalist world economic order" (West Africa, 1983b) ${ }^{7}$. At the same time, Ghana was not shy to show its confidence in the Soviet Union for material help not only for Ghana but also for South Africa and Namibia under the imperialist Apartheid regime (West Africa, 1983a). The foreign policy change in Ghana can be explained with the demise of the Marxist JFM and the emergence of the NDM with a development ideology of the theory of New Democracy by Mao ${ }^{8}$. As Maoism did to the Chinese, in the eyes of some Ghanaian elites, it was seen as a viable substitute for imperialist capitalism and for radical Soviet Socialism (Tu, 2008; Yu, 1988). However, instead of materialising the ideology of New Democracy, Mao's ideology and the NDM were used and manipulated by Rawlings in his search for power and foreign aid.

\section{Conclusion}

The New Democratic Movement (NDM) was not the most influential body in the beginning of the Rawlings regime but it became the most supportive and influential group as Rawlings changed Ghana's foreign policy toward the IMF in 1983. The elite in the NDM, who were inspired by Mao's New Democracy, argued that instead of rapid socialisation excluding some classes in Ghana, Ghana should take time to reach fuller socialism by entailing various classes in Ghana and by collaborating with international capitalists. This approach originated from Mao's New Democracy and Rawlings found a good use of it, as a political tool to check his rivals, the radical socialist June Forth Movement (JFM). The paper highlighted 
the emergence of the NDM in a context of the foreign policy change in 1983. Rawlings needed to tame radical socialism among elites to collaborate with the IMF and, at the same time, to maintain his socialist support groups. In the process, the NDM and its New Democracy ideology was chosen and upheld as a principle of Ghana's foreign policy change. However, the New Democracy ideology was not materialised in Ghanaian economic development. Instead of being implemented as a development ideology, the New Democracy ideology was used as a political tool for eliminating a threat to the regime and abandoned when it was no longer useful. The high-time of the NDM did not last long. The harsh restructuring programme imposed by the IMF marginalised the Ghanaian population and the elites in the NDM turned to become critics of the Rawlings regime. Rawlings responded to the criticism by destroying the NDM and the remnants of leftists using the rightist groups in 1985. Finally, in January 1990, several key members of the NDM were arrested or detained and the NDM was disbanded, after which the regime turned Ghana's economic development direction towards full-fledged capitalism.

\section{Endnotes}

1. The PP under Busia in 1969 undertook the Rehabilitation Programme led by the IMF. It did not have any significant impact on spurring economic growth despite the 30 per cent devaluation of the currency which took place as part of the programme (Boafo-Arthur, 1999:78).

2. Mainly six political organisations provided varying degree of support for Rawlings regime: the June Forth Movement, the New Democratic Movement, the Kwame Nkrumah Revolutionary Guards, the Africa Youth Command, the People's Revolutionary League of Ghana and Pan-African Youth Movement. However, the major two was the JFM and the NDM.

3. In fact, Ghana has a long tradition of a Ghanaian version of the non-aligned movement (NAM) which claims neutrality in expression but leans towards social- 
ism in practice. Regarding this argument, consult a $\mathrm{PhD}$ thesis of the author (Kim, 2014:118-121)

4. Antwi-Danso is senior research fellow at the Legon Centre for International Affairs and Diplomacy. Interview was conducted in Ghana on 24 May 2013.

5. Ibid.

6. According to the Guidelines, a People's Shop has multiple purposes such as distribution of commodities, and co-operation for production, marketing and obtaining inputs for farmers. The creation of a People's Shop originated from the scarcity of commodities in previous regimes in Ghana. Private shops yielded high profits due to scarcity and the PNDC attempted to control the supply by introducing People's Shops where the PNDC distributed supplies.

7. Some writers find the Rawlings regime to be populist rather than Communist because despite the strong anti-Western rhetoric in the beginning of the regime, there was nothing revolutionary in Rawlings' policy (Kilson, 1987; Toye, 1991; Bentsi-Enchili, 1983; Chazan, Naomi 1991). Jeffries (1990:160) also argues that, based on the speeches of Rawlings when he came back to power in 1982, the leftists failed to convert him between 1979 and 1982 and Rawlings was "a populist patriot" who was "determinedly non-ideological, even anti-ideological" regarding Ghana's economic conditions.

8. China and Ghana established diplomatic relations in 1960. Kwame Nkrumah, who did not want to get involved in the Sino-Soviet feud visited Moscow and continued to visit Beijing thereafter (Shinn, 2012:288). In Beijing Nkrumah received a US\$ 20 million interest free loan which was a better deal than he got from Moscow. The two countries continued with good relations and Ghana was one of the ten African countries Zhou Enlai made a visit to between 1963 and1964. Zhou Enlai pledged a US\$ 22 million loan in his visit to Ghana. The first aid was sent from China to Ghana in 1964 (Davies, 2008; Tu, 2008). The amicable relations severed, however, in 1966 when Nkrumah was overthrown by a military regime during his visit to Beijing. The military regime accused Beijing of supporting 
AFRICAN

ousted Nkrumah in a comeback to power. The severed relations became reestablished in 1972 and Rawlings made the first visit as head of Ghana, since Nkrumah, to China, in 1985. It is ironic that Ghana and China made a similar foreign policy turn around 1982. In the $12^{\text {th }}$ Communist Party of China (CPC) National Assembly in 1982, a shift in foreign policy from "war and revolution" to "peace and development" was upheld in China. In Ghana, the negotiation with the IMF was practically agreed at the end of 1982 and it was also a shift from revolution to economic growth.

\section{Bibliography}

Agyeman-Duah, B. 1987. Ghana, 1982-6: The Politics of the P.N.D.C. The Journal of Modern African Studies, 25(4): 13-642.

Ahiakpor, J.C. 1985. The Success and Failure of Dependency Theory: The Experience of Ghana. International Organization, 39(3): 535-552.

Akokpari, J. 2005. Ghana: Economic Dependence and Marginalized Foreign Policy-Making, in Diplomacy and Developing Nations: Post-Cold War Foreign Policy-Making Structures and Process. Abingdon: Routledge. 181-199.

Allison, G. T. 1971. Essence of Decision: Explaining the Cuban Missile Crisis. Harper Collins Publishers.

Antwi-Danso, V. 2013 . Senior Research Fellow, Legon Center for International Affairs and Diplomacy. Personal interview. 24 May.

Armstrong, R. 1996. Ghana Country Assistance Review: a study in development effectiveness. [Online] Available at: http://www-wds.worldbank.org/ external/default/WDSContentServer/IW3P/

IB/1999/09/17/000178830_98101912001750/Rendered/PDF/ multi_page.pdf [2013, July 2].

Aryeetey, E. \& Cox, A. 1997. Aid Effectiveness in Ghana, in Carlsson, J., So- 
molekae, G. \& v. d. Walle N. (eds). Foreign Aid in Africa: Learning from Country Experiences. Uppsala: Nordiska Afrika institutet. 65-111.

Bentsi-Enchili, N. K. 1983. Review of 1982: Ghana, Shaping a Revolution. West Africa, 3 January: 5-7.

Bing, A. 1984 Popular Participation versus People's Power: Notes on politics and power struggles in Ghana. Review of African Political Economy, 31 Dec: 91-104.

Biswal, T.P. 1992. Ghana: Political and Constitutional Developments. Northern Book Centre.

Boafo-Arthur, K. 1993. Ghana's External Relations Since 31 December 1981, in Gyimah-Boadi, E. (ed). Ghana under PNDC Rule. London: CODESRIA. 135-153.

Bottomore, T. B. 1964. Elites and Society. Middlesex: Penguin Books Ltd.

Brydon, L. \& Legge, K. 1996. Adjusting Society: The World Bank, the IMF and Ghana. London: Tauris Academis Studies

Burton, M. \& Higley, J. 2001. The Study of Political Elite Transformations. International Review of Sociology, 11(2): 181-199.

Chazan, N. 1991. The Political Transformation of Ghana under the PNDC, in Rothchil, D. (ed). Ghana: The Political Economy of Recovery. Boulder: Lynne Rienner. 21-47.

Davies, M., Edinger, H., Tay, N. \& Naidu, S. 2008. How China Delivers Development Assistance to Africa. Research paper by the Centre for Chinese Studies, University of Stellenbosch, South Africa.

Frimpong-Ansah, J. H. 1991. The Vampire State in Africa: The Political Economy of Decline. Oxford: James Currey.

Fuso, A. K. \& Aryeetey, E. 2008. Ghana's Post-Independence Economic Growth: 1960-2000, in The Economy of Ghana: Analytical Perspectives on Stability, 
AFRICAN

Growth and Poverty. Oxford and Accra: James Currey and Woeli Publishing Services. 36-77.

Hansen, E. 1987. The State and Popular Struggles in Ghana, 1982-86, in Nyong'o P. A. (ed). Popular Struggle for Democracy in Africa: Studies in African Political Economy. London: Zed Books Ltd. 170-208.

Hermann, C.F. 1990. Changing Course: When Governments Choose to Redirect Foreign Policy. International Studies Quarterly, 34(1): 3-21.

Huntington, S. P. 1968. Political Order in Chaning Societies. London: Yale University Press.

Hutchful, E. 2002. Ghana's Adjustment Experience: The Paradox of Reform. Unrisd Geneva.

Jeffries, R. 1982. Rawlings and the Political Economy of Underdevelopment in Ghana. African Affairs, 81(324):307-317.

Jonah, K. 1989. Changing Relations between the IMF and the Government of Ghana 1960-1987, in: Hansen, E. \& Kwame, A. N. (eds). The State, Development and Politics in Ghana. Dakar, Senegal: Codesira Book Series. 94115 .

Leith, J.C. \& Söderling, L. 2003. Ghana-Long term Growth, Atrophy and Stunted Recovery. Uppsala: Nordiska Afrikainstitutet

Levitsky, S. \& Way, L. A. 2010. Competitive Authoritarianism: Hybrid Regimes after the Cold War. New York: Cambridge University Press.

Lowi, T. J. 1967. Foreign Policy as a Issue-Area, in Domestic Sources of Policy. New York: The Free Press. 11-51.

Kerstiens, T. 1966. The New Elite in Asia and Africa: A Comparative Study of Indonesia and Ghana. New York: Ferderick A. Praeger.

Kilson, M. 1987. Anatomy of African Class Consciousness: Agrarian Populism in 
Ghana from 1915 to the 1940s and Beyond, in Markovitz, I. L. (ed). Studies in Power and Class in Africa. New York: Oxford University Press. 50-66.

Kim, S. 2014. The Political Economy of Aid-oriented Foreign Policy Change: Elite perspectives on Mercantilism in Korea and Ghana. PhD thesis. Cape Town: University of the Western Cape.

Mills, C. W. 1956. The Power Elite. New York: Oxford University Press.

Minutes of East X'Borg Zone B PDC, 1982. 22 February.

Mohan, G. 1996. Adjustment and Decentralization in Ghana: A Case of Diminished Sovereignty. Political Geography, 15(1): 75-94.

Moon, B.E. 1985. Consensus or Compliance? Foreign Policy Change and External Dependence. International Organization, 39(2): 297-329.

Moravcsik, A. 1997. Taking Preferences Seriously: A Liberal Theory of International Politics. International Organization, 51(4): 513-553.

Nugent, P. 1995. Big Men, Small Boys and Politics in Ghana. New York: A Cassel Imprint.

Okeke, B. E. 1982. 4 June: A Revolution Betrayed. Enugu, Nigeria: Ikenga Publisjers.

Oquaye, M. 2004. Politics in Ghana, 1982-1992: Rawlings, Revolution, and Populist Democracy. Accra: Tornado Publications.

Rathbone, R. 2000. Nkrumah and the Chiefs: The Politics of Chieftaincy in Ghana 1951-1960. Oxford England and Athens: J. Currey.

Rothstein, R. L. 1976. Foreign Policy and Development Policy: From Nonalignment to International Class War. International Affairs, 52(4): 598-616.

Shillington, K. 1992. Ghana and the Rawlings Factor. Singapore: The Macmillan Press Ltd. 
AFRICAN

Shinn, D.H. \& Eisenman, J. 2012. China and Africa: A Century of Engagement. University of Pennsylvania Press.

Toye, J. 1991. Aid and Power: The World Bank and Policy Based Lending, Vol.2. London: Routledge.

Tsikata, K. 1968. The Goal of Revolution. Accra:Nsmamknow Press.

Tu, J. 2008. Sino-African Relations: Historical Development and Long-term Challenges. China: An International Journal, 6(2): 330-343.

Yu, G.T. 1988. Africa in Chinese Foreign Policy. Asian Survey, 28(8): 849-862.

West Africa, 1982a, January 11. And after the return...?. West Africa, No. 3362:67.

West Africa, 1982b, January 11. Constitution and Politics Suspended. West Africa, No. 3362:70-71.

West Africa, 1982c, March 8. Twenty-five Years of Ghana. West Africa, No 3370:627.

West Africa, 1982d, April 12. The US Interest in Africa. West Africa, No. 3375:967.

West Africa, 1982e, July 5. PNDC's Relations with Other Countries. West Africa, No. 3387:1754-1756.

West Africa, 1983a, January 24. Relations with the USSR. West Africa, No. 3415:236.

West Africa, 1983b, February 7. 'Time for frank and free debates'. West Africa, No. 3417:370.

Whitfield, L. \& Jones, E. 2008. Ghana: The Political Deminstions of Aid Dependence. Standford University, Global Economic Governance Program Working paper 2007/32.

World Bank, 1983. Ghana, Policies and Program for Adjustment. Washington 
DC: World Bank.

World Bank, 2013. World Development Indicators. [Online]. Available at: http:// data.worldbank.org/country/ghana [2013, June 5].

Zimmerman, W. 1973. Issue Area and Foreign-Policy Process: A Research Note in Search of a General Theory. The American Political Science Review, 67 (4): 1204-1212. 
AFRICAN

From non-interference to preponderance: China's future grand strategy in Africa

\author{
By Okolo Abutu Lawrence*
}

Department of World Economy

Xiamen University, China

\begin{abstract}
The emergence of China in Africa is fast transforming the geo-political and economic landscape of the region. The policy of non-interference embedded in the Five Principles of Peaceful Coexistence largely prevents Beijing from interfering in the domestic affairs of other nations; and there has been no marked change in her interests, plans and relations. China strategically toes the same line she has pursued from 1954: that of non-interference. The paper argues that the strategy of non-interference is not in sync with present realities. Beijing needs to revisit this strategy in order to protect its economic investments and political interests, which have come under threat in recent years. The paper concludes that a choice mechanism would be more suited within China's approach. It proposes the strategy of "preponderance", which is an alternative to Beijing's current grand strategy.
\end{abstract}

*Okolo Abutu Lawrence is a PhD Candidate at the School of South-East Asian Studies in the Department of World Economy at Xiamen University, China. 


\section{Introduction}

There are many divergent arguments about "preponderance" by different scholars however; the paper shall briefly examine some significant ones. According to the oxford dictionary, preponderance means superiority in weight, power, importance or strength. Furthermore, Melvyn Leffler (1992:1) observed that "to prevent fears from becoming realities, and to prevent a repeat of past mistakes, the United States developed a foreign policy based on a 'Preponderance of Power'". The policy called for a grand strategy which identified national security interests and then formulated ways to attain them. The plans entailed the use of economic, military, political, and diplomatic means. In addition, Christopher Layne (2007) agreed that national security demanded an "open international economy and a favourable balance of power". He concludes that America proposed: 1) to rebuild Western Europe; 2) to rely on a reconstructed Germany and Japan to maintain a viable and strong Western European economy; and 3) to promote gradual decolonisation of third world in order to secure needed cheap raw materials for the Western European infrastructure (Layne 2007).

China's avowed position to not have a military presence in Africa is now stale as it is not in consonance with today's economic reality and emerged world order where investing powers use all their influence to ensure that nations benefitting from their investments provide them with a military base to ostensibly watch over their hosts while using their military presence to guard their investment. Thus, Beijing should take more interest in having a military presence in Africa so as to safeguard its investments rather than to hide under a parochial strategy of noninterference.

The dominant view of some critical analysts is that over the past decade the United States of America's (USA) empire-building has suffered a series of economic shocks, experienced military defeats, and now faces severe competition and the prospect of further economic losses. The emergence of China in Africa is fast transforming the geopolitical economy of the region. Beijing strategically toes the same line of non-interference in the internal affairs of any nations (Alula, 2013:1). 
Although non-interference applies to military interventions and regime change, the principle has been Beijing's modus-operandi in its investment and economic relations with Africa and the rest of the world (The Economist, 2014:1).

However, according to Alula (2013:1) states that there has been no corresponding change in Beijing's interests and relations; the Asian power is following the same policy it pursued from 1954 till present: that of non-interference. Whether this grand strategy will serve her interests in the twenty-first century is arguable. This research paper looks to stimulate a more searching argument about Beijing's future grand strategy options because of her chameleonic posture in Africa. To fulfil this task, the research compares the policy of non-interference to a proposed alterative grand strategy, namely: preponderance.

The reason for adopting an alternative grand strategy is prospective: though sustainable for perhaps another decade, the strategy of non-interference cannot be sustained much beyond that period. The time to think about alternative grand strategies is now, before Beijing is overtaken by events.

The research paper is structured as follows. Firstly, the paper analyse the policy of non-interference, with a clear focus on its theoretical underpinnings and policy components. Secondly, the paper demonstrates non-interference policy weaknesses. Thirdly, the paper outlines the elements of an alternative grand strategy, namely, preponderance, which the researcher felt Beijing is adopting in Africa in the twenty-first century.

\section{Beijing non-interference strategy: a pattern of continuity.}

China has pursued the same grand strategy, non-interference, since the late 1950s. The non-interference strategy states that Beijing does not meddle in the internal affairs of nations; it is devoid of political conditionality (Alula, 2013:1). The noninterference grand strategy has been serving China well since (1954). The strategy derives from the Five Principles of Peaceful Coexistence: mutual non-aggression, non-interference in each other's internal affairs, mutual respect for sovereignty and territorial integrity, "equality and benefit, and peaceful coexistence. [This grand 
strategy] was designed to reach out to non-communist [nations] in Asia as well as reflect [solidity] with newly independent post-colonial states in Africa, with an emphasis on territorial sovereignty defined in the most rigid and traditional Westphalian terms. [However], non-interference applies to military interventions and regime change, the principle has been [Beijing's] modus-operandi in its [economic] and [investment] interactions with Africa and the rest of the world" (Brown, 2013:1). Chan (2013:114) asserts that "Beijing's non-interference in internal affairs' a cornerstone of its foreign policy, although the recent engagement of its military and navy in Sudan and Somalia at the behest of the African Union seem to point to a different way in the future".

In the same address, it is worth remembering that the strategy was welcomed and embraced by many African countries as it came to represent, particularly from the early 1990s onward, an alternative to the USA conception of a new kind of world order (Alula, 2013:2) one in which the "Third World" nations, found it increasingly complicated to manage their own political and economic affairs. Alula Ilaysu (2013) argued that non-interference was viewed as a refreshing departure from the prescriptive policy of the USA and the European countries which forced African leaders into the straitjacket of the so-called "Washington consensus" with its structural adjustment programs designed to mould Africa in the image of the "West". In the same vein, Alula found that (2013: paraphrased): structural adjustment programs and other Western deriving economic prescriptions for Africa have proved detrimental to African nations, at worst, and unfit to African socio-economic and political realities, at best. By contrast, the hallmark of Beijing's economic relations with Africa, in line with its non-interference grand strategy and its nonprescriptive nature was embraced enthusiastically by many African leaders. The strategy's emphasis on the state as a sole principal actor for economic development, contrary to the USA and EU vilification of the state and emphasis on the private sector, also meant that African countries with a yet to mature private sector fully welcomed Beijing as their economic partner and source of capital for development. That said, the strategy has been applied selectively to suit China's interest at various times, beginning in its earliest days of implementation, circa 1960s and 
1970s when Beijing supported revolutionary movements in Africa and Asia. More often than not, at the United Nations Security Council (UNSC), Beijing often abstains from voting on resolutions that mandate sanctions or interventions. This allows several interventions to go ahead without China having to reverse its commitment to non-intervention" (Alula, 2013, 2).

In the similar development, in the case of Libya, according to Hughes (2012) Beijing expressed grave reservations over the North Atlantic Treaty Organization (NATO) campaign; it chose not to use its UNSC veto to block the intervention. Instead, it abstained when Resolution 1973 was passed to impose a no-fly zone and to authorise all measures necessary to protect civilians, though it supported the UNSC in imposing an asset freeze, travel ban and arms embargo against Gaddafi's regime. Interestingly, Beijing's adoption of a flexible and pragmatic approach in its diplomatic stance on Libya was arguably to protect its economic interests in the country, which was contrary to its principle of non-interference in the domestic affairs of other countries. More so, there are growing concerns that the strategy is merely used to benefit Beijing's investment and interests in Africa as it largely overlooks realities of contemporary crises and socio-political realities on the continent. This is because in practical terms, the application of the policy has been tailored to suit Chinese interest wherever it is at stake on the continent (Hughes, 2012).

\section{Understanding non-interference and south-south co-operation}

The definition of non-interference is certainly far from perfection; however it represents Beijing's very articulation of the principles by which it has largely and consistently dealt with its South-South allies. After Zhou and Nehru's meeting in 1954, various delegates from 29 African and Asian countries converged on Bandung, Indonesia, affirming the Five Principles of Peaceful Coexistence which would shape the agenda of the emerging Non-Aligned Movement (NAM). At the Bandung conference in 1955, The Bandung Declaration served as a watershed in modern history, initiating the age of the non-aligned world, which in turn revolutionised relations between China and its neighbours as well as other members of 
the NAM, who all adopted the five principles to guide their foreign relations (Alden \& Hughes, 2009: 563-584).

In 1955, Zhou Enlai of China, Sukamo of Indonesia, Nehru of India and the Egyptian leader, Nesser, coming from Africa were key figures and decision makers at the Bandung Conference. They supported the idea that a resolution on world peace should be based on the Five Principles of Peaceful Coexistence. Similarly, China maintains that the internal affairs of any state are its own responsibility and China's investment in the war ravaged countries such as Nigeria, Gabon and the Democratic Republic of Congo reflects the policy (Tukumbi, 2007:8-16).

The emergence of China as a global power, along with the rise of other BRICS members (Brazil, India, Russia and South Africa), is facilitating their economic growth in Africa. The BRICS have emerged as donors and established a different way of economic co-operation: south-south economic co-operation (Gordhan, 2011:2). Through increased engagement mainly in infrastructural development that emphasise win-win co-operation, mutual support and respect, and noninterference in domestic affairs, the BRICS have increased their trade with Low Income Countries (LICs). For instance, the trade levels between the BRICS and the African continent has increased ten-fold over the past decade to reach a value of some US\$ 340 billion in 2012 (Hamza, 2013:3) More so, many of the BRICS' imports and investments in Africa are still mainly dominated by energy and commodity goods (for example, oil and mineral ores) whose extraction may have high environmental and social impacts (Tales, 2013). The BRICS and their public financial institutions have gone beyond the Organization for Economic Cooperation and Development (OECD) Development Assistance Committee (DAC) and the traditional international financing institutions (IFIs) in terms of aid conditionality. Thus, the practices of BRICS has changed the landscape of development assistance financing through more competitive concessional/grant aid flows, tied aid credits and the so-called "infrastructure-for-resources" loans. More particularly, Brazilian, Indian and Chinese public financial institutions have established schemes that pre-allocate credits which are tied to market-oriented deals or natural -resource access by State Owned Enterprises (SOEs) and Government Linked 


\section{AFRICAN \\ EAST-ASIAN \\ AFFAIRS \\ THE CHINA MONITOR}

Companies (GLC) (Guerrero, 2012:1).

In the same breath, as China "is continuously prodded to distinguish its policies and engagements from that of the [USA and EU] in Africa, [image] is of paramount [significance]. For [Beijing], keeping a carefully managed image in Africa will be critical to undercutting the arguments of neo-colonialism that are levied by its critics. The [strategy] of non-interference has always been [China's] answer to queries about its policy and economic gains in Africa" (Richard, 2012).

Andrew, (2007) observes that the Five Principles of Peaceful Coexistence still serves:

"a useful purpose. They offer an alternative to the [USA] conception of a new kind of world order-one in which international regimes and institutions, often reflecting [USA] interests and values, limit the rights of sovereign states to develop and sell weapons of mass destruction, repress opposition and violate human rights, pursue mercantilist economic policies that interfere with free trade, and damage the environment. China's alternative design for the world stresses the equal, uninfringeable sovereignty of all states-large and small, Western and nonWestern, rich and poor, democratic and authoritarian - each to run its own system as it sees fit, whether its methods suit [the West] or not. Another Chinese term for such a system is [multipolarity]" (Andrew: 2007).

That is, roughly speaking, a vision of the world as a stage where a variety of policies, unique to specific nations, may be implemented without friction. Five Principles of Peaceful Coexistence explains why USA should not be able to impose its political ideology on weaker nations. Thus the core idea behind the strategy as interpreted by China today is sovereignty - that one state has no right to interfere in the internal affairs of another state (Andrew, 2007:1-2). Finally, the strategy of non-interference has variedly won the hearts of some African leaders who perceived it as a much-needed break from the quid pro quo relations with the "West".

\section{Non-interference in Africa and the post-Cold War: a critique}

In this section the paper critiques the strategy of non-interference, focusing on Chinese involvement in some parts of Africa, using different methods in expanding its economic sphere of influence. 
According to Aubyn (2013:20) that China's role in African security issues has been guided by the key principle, of non-interference which Chinese government does not allow interference in its own domestic affairs. However, there are growing concerns that the strategy is merely to benefit Beijing's economic and investment interests in African continent as it largely overlooks realities of contemporary conflicts and socio-political realities on the continent. This is because in practical terms, the application of the strategy has been tailored to suit Chinese interest wherever it is at stake on the continent (Aubyn, 2013:20). For instance, Beijing supplied the Sudanese government with arms and weaponry even when the Darfur upheaval was still ongoing. In fact, the majority of these arms were used for persistent and systematic violations of human rights by government and rebel forces. The supply of arms to the government of Sudan for example, indicated a paradigm shift in Beijing's strategy (Large, 2008:93-106). More so, in its desire to maintain a reliable source of oil, China has indirectly but actively sought to sustain a form of political control within Sudan: that of the ruling National Islamic Front which clearly suits its own narrowly-defined interests (Large, 2008).

In a similar way, Ali Askouri (2014) asserts that since the mid-nineties, Beijing has been supplying the government of Sudan with all types of weaponry, and ammunitions, including jet fighters, helicopters, small arms and machine guns, amongst other things; not only that, but Beijing has upped its economic support for the internationally isolated government pouring billions of US dollars into ill prepared infrastructure projects (such as the Merowe dam). Despite the excessive human rights violation that the government security committed in these projects, China turned a blind eye to the suffering of the communities and continued to fuel the repressive machinery of the government with arms and money (Large, 2009:614).

Guinea Bissau is also in the picture; Beijing's "focus is on extracting the raw materials necessary to support its economic growth and soaring energy demands, while also trying to cement its place as a global leader. China continues its diplomatic relations with and financial support to Guinea-Bissau despite the country's [political] instability. China has financed, among other things, the Ceba River 
Dam, international scholarships, rice shipments and even unpaid government salaries. In return, China has received exclusive rights to Guinea-Bissau's deep-water fisheries and is involved in oil exploration to extract [Guinea] Bissau's suspected reserves. [Some] Chinese [State owned] companies were criticised by environmentalists for the deforestation of [Guinea] Bissauan territory shipping over 800 containers of protected timber to China in June 2013. Thus China provides muchneeded donations and development, and then utilises its influence for the extraction of resources" (Kyle, 2013). At the same time, Alden and Hughes (2009) noted that when the non-intervention policy is employed to justify opacity in dealings with elites, from aid disbursements to business engagement, the view becomes more widespread that Beijing is just another hegemon out to exploit the African continent (Alden \& Hughes 2009:569).

More importantly, in 2010, China National Offshore Oil Cooperation (CNOOC) "forcefully lobbied the Ghanaian government for the [US\$4] billion oil shares on sale by Kosmos Energy from ExxonMobil. With such competitive resource deals comes the increasing lure to continuously flirt with the powerful domestic actors to ensure the uninterrupted access to these strategic resources [while minimising] local discontent. This dilemma will continue to challenge non-interference as a policy that sets Beijing from the [traditional trading partners] in Africa" (Richard, 2012:2).

More so, Richard (2012:3) wrote that "the Arab Spring and other political movements that have swept through parts of North Africa have also strained Beijing's non-interference strategy. Saddled with the policy of non-interference, Beijing's response to this unexpected political movement is being closely monitored by its critics. Some of China's strategic responses during the Arab Spring, such as its decision to meet with Libyan opposition forces in Qatar before the demise of Muammar Gaddafi, have revealed the elasticity of non-interference" as Beijing positioned itself to be a significant power in the aftermath of the political and social turbulence (Richard, 2012:2-3).

"In this case and others, China arguably broke with the tenets of non-interference 
for the sake of a ['resourceful'] posterity. Then again, this is possible given that after six decades, the [strategy] of non-interference is still amorphously defined, hence mostly perceived as a doctrine that [characterises] Beijing's passivity in a rather complex international system where states must often make hard choices" (Cheru \& Obi, 2010).

Another weakness of non- interference from Beijing is poor labour practices by Chinese government companies and by Chinese private companies. Chinese companies establishing operations on the continent typically use a mostly Chinese labour force rather than locals including cooks and relatives, these attitudes by Chinese companies precipitated a considerable resentment in African communities. More so, this resentment has been tapped into by a number of African politicians and has put pressure on African governments to respond to exploitative labour practices of Chinese companies (Cheru \& Obi, 2010).

Beijing has placed a high priority on preserving strong relations with its African energy suppliers; unfortunately China's investments and its strategy of nonintervention in the local affairs frequently works in favour of some of the most infamous African dictators. Sudan, Zimbabwe and Congo-Brazzaville, who all have grim human rights records, have accounted for 82 per cent of Beijing's crude -oil supply in Africa. Chinese engagements with "no strings-attached" allow these regimes to ignore good governance, norms and human rights issues (Nora, 2012:2). In the similar development, "the Angolan government sought funds to rebuild after [the] civil war; it looked to the International Monetary Fund, [which] was determined to force the regime to be more transparent. However, Angola ceased negotiations when [Beijing] offered a better alternative: China's exportcredit agency counter-offered with a [US\$ 2] billion and asked in return that 70 per cent of future substantial construction contracts be awarded to Chinese businessmen in addition to also guaranteeing more oil for China. Therefore although enthusiasts of the relationship may point to the fact that China has brought Angola more revenue, (Angola was China's top trading partner in 2010-with a trade value of US\$ 24.8 billion). This one example shows how this relationship is not necessarily benefitting the population of African countries" (Nora, 2012:1). 


\section{Preponderance: an alternative grand strategy for Beijing in Africa}

An alternative to the strategy of non-interference is "Preponderance". As discussed above, "Preponderance" means superiority in weight, power, importance or strength. In this section the paper describes Beijing's economic and military presence in Africa as preponderant. Beijing has exhibited greater commitment to peacekeeping activities by increasing its participation in UN operations and peace building efforts as well as providing diplomatic support to African countries during debates at the (UNSC). Since its first participation in the UN Transition Assistance Group (UNTAG) in Namibia in 1989, China has deployed its personnel to African countries such as Liberia, Sierra Leone, the Democratic Republic of Congo (DRC), Burundi, Sudan, Western Sahara, Cote d'Ivoire and Mozambique (Aubyn, 2013:16). Beijing is currently Africa's largest trading partner (Abutu, 2013:57-59). With all these qualities, Beijing is capable of taking responsibility in order to protect her economic interest in Africa. However, three distinct factors appear to motivate Beijing's behaviour in African affairs.

The first significant factor is that Africa is a major market for Chinese manufactured goods such as textiles, clothing, consumer goods and machine tools and at the same time, the import market of energy (oil) and raw materials such as minerals (copper, bauxite, uranium, aluminium, manganese, iron ore), precious stones, timber, cotton, and fish products (Rotberg, 2008). For this important reason, securing markets for Chinese goods and the supply of raw materials from Africa for Beijing's manufacturing companies has been a major priority in China's engagement with the continent. More importantly, trade between Africa and China has grown at a breath-taking pace, "against the background of sluggish global economic recovery in recent years; China-Africa trade development has maintained comparatively rapid momentum. In 2012, the total volume of China-Africa trade reached US\$ 198.49 billion, a year-on-year growth of 19.3 per cent. Of this, US\$ 85.319 billion consisted of China's exports to Africa, up 16.7 per cent and US\$ 113.171 billion was contributed by China's imports from Africa, up 21.4 per cent. Total China-Africa trade volume, China's export volume to Africa and China's import volume from Africa all reached new highs" (Xinhuanet, 2013). 
Another factor is that China's broader foreign policy objective of expanding its political spheres of influence and desire to be seen as a responsible global power that is contributing to international public good of maintaining peace and security is also accountable for its somewhat active role in African security (Aubyn, 2013:15). That is to say, Beijing's interest in African security issues is also motivated by its global ambitions of being recognised as a distinct power on the international scene. For example, apart from contribution to UN peacekeeping operations in Africa, China's participation in anti-piracy efforts in the Gulf of Aden is symptomatic of this assertion (Kostecka, 2010). Though some analysts and scholars would argue that China's involvement in the Gulf of Aden was motivated by "geo-politics and the protection of national economic interests, it also reflects its willingness to share the burden of upholding international peace and security as a responsible big power" (Saferworld, 2011).

The third factor is that Beijing has many investments, especially, in the energy and mineral extraction sectors across the continent, most notably in: Nigeria, Sudan, South Sudan, Algeria, Zambia, Ethiopia and Kenya. In Sudan, for instance, China's National Petroleum Corporation (CNPC) dominates the oil sector with an investments which are valued to be over US\$ 7 billion (Hellström, 2009: 13). Other Chinese national oil Companies such as the China Petroleum and Chemical Corporation (Sinopec), Petro-China and the China National Offshore Oil Corporation (CNOOC) also have considerable investments in numerous African countries (Taylor, 2006). In addition, in the mineral extraction sector, Chinese companies have been given access to gold mining in Eritrea, manganese in Côte d'Ivoire, Ghana and Gabon, bauxite in Guinea, titanium in Kenya, uranium in Niger, chromium in South Africa, copper in Zambia, oil in Nigeria and coal and platinum mines in Zimbabwe (Hellström, 2009:19-20). In addition, most of these investments have come under serious threat due to conflicts and political instability. For example, In west Africa and to be precise, Ghana since 2011, there have been several violent clashes between local mining communities and small-scale Chinese miners who are often accused of illegal gold mining activities known in Ghana as "galamsey". Such activities have also caused huge environmental destruction to 
farmlands and rivers through the use of heavy machinery, bulldozers and pay loaders (Aning \& Aubyn, 2013). In order to protect and safeguard its economic interests and investments, China has inevitably been forced to take a keen interest in the stability and development of those countries where its companies have invested. This partly explains why in certain conflict situations, like that of Sudan where its interests were at stake, Beijing had to be flexible on its dogma of state sovereignty and non-interference to the extent that, it had to publicly encourage Khartoum to allow UN peacekeepers into Darfur (Aning \& Lecoutre, 2009; Large, 2007).

In recognition of this, China's policy of non-interference has become ambiguous and complex in some parts of Africa. However, as discussed above, preponderance suggests that in reality non-interference policy does not mean that China sits back and watches without getting involved or that non-interference equals indifference. China relaxes its strategy, usually allowing China to protect her interest wherever is at stake in the region. In addition, Beijing supplied arms to the Sudanese government during the Darfur crises which was condemned by the United Nations and other civil right activists in the world. This reinforced perceptions that Beijing supports pariah regimes on the continent especially after the latter's involvement in Zimbabwe (Aubyn, 2013:21).

Furthermore, Zimbabwe is another significant example that reflects Beijing's support for a Pariah regime. The Zimbabwean government strategically toed the line of structural adjustment programmes since the 1990s, and in the wake of protest from urban dwellers and ex-soldiers embarked on land reform of white-dominated commercial land. Its defiance of the norms of property law of the Zimbabwean constitution drew criticisms from Western media, government and other nongovernmental organisation (NGOS). The criticism increased steeply after the Zanu -PF led government rigged elections against the opposition Movement for Democratic Change, and criticism turned into targeted sanctions against the regime. Foreign direct investment dried up and Mugabe's government faced economic hardship. The Zimbabwean government searched for new partners to replace the Western investors and development assistance programmes. Beijing's willingness to 
publicly embrace Mugabe, despite international sanctions imposed from 2002 onwards, precipitated in Harare's official promulgation of its "Look East" strategy in 2005. Similarly, Mugabe stated that:

"We are returning to the days when our greatest friends were Chinese. We look again to the East, where the sun rises, and no longer to the West, where its sets" (Alden, 2007:65).

There is thus a need for Beijing to acknowledge that its policy of non-interference does not fall in line with the contemporary realities and verities of conflict and political instability in some parts of Africa. Using its preponderant status as a global economic power in addition to its veto power in the UNSC, China needs to play a much greater role in the prevention, management and resolution of African security challenges to establish sustainable peace and stability on the continent. If not, the consequences of conflicts and political instability for Chinese investments and economic interest in Africa could be extensive. Playing an active role in African security issues would invariably help change the perception that Beijing is purely exploiting African countries and is Africa's new imperial master rather than a development partner (Hellström, 2009:19).

\section{Conclusion and Recommendation}

According to Brown (2013:1) "the foreign policy of the People's Republic of China has been predicated on non-interference for more than half a century, respect for the sovereignty of others, non-aggression and peaceful co-existence. These were the principles set down by Premier Zhou Enlai at the Bandung Peace Conference in 1955". Brown, further argued that while Beijing strategically toes the same line of non-intervention in the internal affairs of other countries, it has not practiced what it preached (Brown, 2013:1). Frequently Africa and China have "strengthened their economic and trade relations which many see as complementary. [However, Africans] need access to capital, foreign direct investment (FDI) and technology transfers while [Beijing] needs [African] raw materials, resources and access to markets for its goods and services despite the asymmetric relations in favour of Beijing, China's investment is not only needed, but is also welcomed 
by some African governments" because of her strategy of non-intervention (Iyasu, 2013:2).

China's projection of soft power in Africa, facilitated in no small part by the promise of non-interference, has in recent years yielded some results by winning the hearts of some African leaders. The policy of non-interference has thus possibly served as one of the mechanism that the Chinese government has used to gain entry into niche markets where it can effectively compete with more established rivals like the USA and the EU. Increasingly, as Beijing has rapidly transformed from a new emerging player forging a foothold on the continent to an established power with substantial investments, assets and citizens in residence - it has become more intimately bound to the internal affairs of its African partners.

China has traditionally adopted a state-centric approach towards each African country governed by principles of state sovereignty and non-interference instead of a one-size-fits-all approach to the whole of Africa (Aning \& Lecoutre, 2009). Much more importantly, the most significant and visible aspect of this growing partnership is perhaps the new US\$ 200 million African Union headquarters in Addis Ababa, Ethiopia, that was donated by the Chinese government in January 2012 (BBC News, 2013). China has arguably been instrumental in supporting the African Union (AU) in its aim to find African solutions to African problems. The Chinese government has, through the provision of both material and financial assistance to the AU, supported the implementation of the African Union Peace and Security Architecture (APSA).

In order to show more commitment to the continent, China for example contributed US\$ 100,000 to the Economic Community of West African States (ECOWAS) Peace fund in 2008. In 2005, China appointed representatives to the South African Development Community (SADC), ECOWAS and the AU, signifying its burgeoning relationship with these organisations. Diplomatically, China has also aligned with the positions of Regional Economic Communities (RECs) at the UNSC. A typical case was in 2008 when China and the Russian Federation vetoed UNSC's measures intended to impose sanctions against Zimbabwe's President Robert Mu- 
gabe and 13 other government and security officials considered responsible for the violent crisis in the country. China supported the offices of SADC and the AU, and called upon all parties not to take any action that might have a negative impact on the situation (UNSC Department of Public Information, 2008).

Conclusively, Beijing preponderance in Africa has increased, particularly since 1990 when China agreed to join in UN peace-keeping responsibilities. In January 2005, 598 Chinese peace keepers were sent to Liberia. Others were sent to Western Saharan as part of the United Nations Mission for the Referendum in Western Sahara (MINURSO), Sierra Leone, the Ivory Coast and the Democratic Republic of Congo (DRC). Beijing presently has military alliances with six African states, four of which are major oil suppliers: Sudan, Algeria, Nigeria and Egypt (Hurst, 2007). To this end, the research submits that it is imperative Beijing uses its status as a global economic power in addition to its veto power in the UNSC. China needs to play a much more significant role in the prevention, management and resolution of African security problems to establish sustainable peace and stability on the continent while protecting its investment. Finally, China and the United States of America can ensure that African security issues take a higher priority in their relations. To this end, trilateral dialogues such as China-Africa-US forums can be initiated to allow for frequent exchanges of views and perspectives on security issues concerning Africa.

\section{Bibliography}

Abutu, O.L. 2013.The Strategic Implications of China-Nigeria Economic Relations.Fudan Journal of the Humanities and Social Sciences 6: 57-59

Askouri, A. 2007.China's Investment in Sudan: Displacing Villages and Destroying Communities, inManji F. and Marks S.(eds). African Perspectives of China in Africa.Fahamu: Nairobi and Oxford.

Alula, A. I. 2013.China's Non-Interference Policy and Growing African Concerns, African Arguments.[Online]. Available: http:// 
AFRICAN

africanarguments.org/2013/07/18/china\%E2\%80\%99s-non-interferencepolicy-and-growing-african-concerns/[2014, March 20].

Alden, C. 2007. China in Africa, . London: Zed Books

Alden, C. \& Hughes, C. 2009. Harmony and Discord in China's Africa Strategy: Some Implications for Foreign Policy.China Quarterly, 563-584.

Andrew, N. J. 2007. The Great Wall and the Empty Fortress: China's Search for Security. New York: WW. Norton.

Aubyn, F. 2013. China's foray into African security and the question of noninterference,African East-Asian Affairs, 7: 13-15.

Brown, K. 2013. Is China's Non-Interference Policy Sustainable?[Online]. Available:http:// www.bbc.com/news/world-asia-china-24100629 [2014, March 20].

BBCNews. 2012.African Union opens Chinese-funded HQ in Ethiopia. [Online]. Available:http://www.bbc.co.uk/news/world-africa-16770932[2014, January 10].

CBCnews.2013. China overtakes U.S. to become world's biggest oil importer:Strong growth and rising auto use push demand despite a slowing Chinese economy.[Online]. Available: http://www.cbc.ca/news/business/ china-overtakes-u-s-to-become-world-s-biggest-oil-importer-1.1958511 [2014, February 11].

Condon, M. 2012. China in Africa: What the Policy of Non-intervention Adds to the Western Development Dilemma. Fletcher Journal of Human Security 27: 5-25.

Embassy of the People's Republic of China in the Republic of Ghana. 2013. China -Ghana relations and the focus of Chinese Diplomacy in Africa.[Online]. Available: http://gh.china-embassy.org/eng/xwdt/t1092973.htm[2014, February 6].

Cheru, F. \& Obi, C. 2010.The Rise of China and India in Africa: Challenges, 
Opportunities and Critical Interventions.Zed Books.

Gordhan: 2011. BRICS and Africa in the new world order [Online] available http://www.southafrica.info/business/trade/relations/bricsorder.htm\#.U68aElVdV3E [2014, June 28].

Gordhan:The Cairo Review of Global Affairs.An Emerging New World Order.

[Online]. Available: http://www.aucegypt.edu/gapp/cairoreview/pages/ articleDetails.aspx?aid=75[2014, March 21].

Guerrero, D.G. The Rise of China and BRICS: A multipolar world in the making? Focus of the Global South.[Online]. Available:http://focusweb.org/ content/rise-china-and-brics-multipolar-world-making[2014, March 15].

Ferim,V.2010. The Ambiguity of China's Non-Interference Policy as A drawback to Peace and Stability in the Sudan. South Africa: University of Fort Hare.

Hurst, C. 2008. China's Global Quest for Oil: China's Oil Rush in AfricaNigeria, The Cutting Edge.

Hellström, J. 2009. China's emerging role in Africa: A strategic overview. FOI Studies in African Security,13:19-20.

Hughes, C. 2012. The Libya Crises and Challenges to China's Non-interference Principle.USAK Analysis.[Online]. Available: http://www.usak.org[2014, February 3].

Kyle, B. 2013. Institute for Security Studies. The US-China 'cold war' in Africa. [Online]. Available:http://www.issafrica.org/iss-today/the-us-china-coldwar-in-africa[2014, February 10].

Kostecka, D. The Chinese Navy's Emerging Support Network in the Indian Ocean. Jamestown Foundation China Brief,10(15). [Online]. Available:www.jamestown.org.single/? [2014, February 13].

Large, D. 2007.Arms, oil, and Darfur: The Evolution of Relations between China and Sudan', Sudan Issue Brief, Small Arms Survey.[Online]. Available: 
AFRICAN

http://www.smallarmssurvey.org-Sudan. [2014, February 12].

Large, D. 2008.From Non-Interference to Constructive Engagement? China's Evolving Relations with Sudan, in Chris, A., Daniel, L. \&Soares de, O. (eds). China Returns to Africa: A Rising Power and a Continent Embrace. Hurst Publishers Ltd: London.

Layne, C. 2007. "From Preponderance to Offshore Balancing: America's Future Grand Strategy, International Security", Vol. 22, No 1, pp. 86-124

Melvyn, L. P. 1992. A Preponderance of Power: National Security, the Truman Administration, and the Cold War. Stanford Nuclear Age Series, gen. ed., Martin Sherwin. California: Stanford University Press.

Nora, L. 2012. China-Africa Relations: Mutually Beneficial?[Online]. Available: http://www.fairobserver.com/article/china-africa-relations-mutuallybeneficial[2014, February 10].

Richard, A. 2012.China's Image Problem in Africa.[Online]. Available: http:// thediplomat.com/2012/10/non-interference-a-double-edged-sword-forchina-in-africa/[2014, March 20].

Rotberg, R. 2008.China's Quest for Resources, Opportunities, and Influence in Africa, in Rothberg, R. (ed).China into Africa.Cambridge: Brookings. 120 .

Steve, H.\& Richard, A. 2010. Beyond the Rhetoric: Noninterference in China's African Policy, African and Asian studies.

Saferworld.China's growing role in African peace and security.[Online]. Available:http://www.saferworld.org.uk/resources/view-resource/500-chinasgrowing-role-in-african-peace-and-security[2014, March 20].

Tukumbi, L. K. 2007. China-Africa Relations in the Post-Cold War Era: Dialectics of Rethinking South-South Dialogue, CODESRIA Bulletin, 1\&2: 8-16.

Tales, R. 2013.The dual role of the BRICS on South-South co-operation for infra- 
structure sustainable development.The south-South Opportunity.[Online]. Available:http://www.southsouth.info/profiles/blogs/the-dual-role-of-thebrics-on-south-south-co-operation-for[2014, March 15].

Xinhuanet.China-Africa Economic and Trade Co-operation.[Online]. Available:http://news.xinhuanet.com/english/china/2013-08/29/ c_132673093_2.htm[2014, March 16]. 
AFRICAN

\title{
Forum*: Leading to environmental sustainability: current status, challenges and prospects of Sino-African low-carbon co-operation
}

\author{
By Liang Yijian** \\ Center for African Studies \\ Yunnan University, China
}

\section{Introduction}

Environmental sustainability is very important for Africa and China. When we seek a solution, low-carbon development at this stage is an important approach. To a certain extent, the low-carbon development is a combination of environmental protection and economic development. China faces great challenges in environmental protection, but it has also made great achievements in low-carbon development, and has certain advantages in terms of capital, technology, and market. The Chinese government has also shown great willingness to change China's development model from high-carbon development to low-carbon development. At present, Africa is at the important stage of protecting its environment while seeking to boost economic development, making low-carbon development a pressing task for African governments. Africa should try to avoid copying the Chinese experience of environmental protection after pollution. In the respect of low-carbon develop-

*Note for the Deputy Editor: Forum pieces are contributions added to each AEAA publication with the aim of promoting and stimulating debate on China-Africa related topics. Forum pieces, unlike all other AEAA articles are not peer-reviewed and allow authors to express their ideas and opinions more freely.

**Liang Yijian is a research associate at the Center for African Studies at Yunnan University. His research interests include Sino-African relations and African governance issues. 
ment, there are many common interests and co-operation possibilities between China and Africa in the age of a heightened China-African relationship. China's technologies in small hydro-power, solar, biogas and other clean technologies are suitable for low-carbon development in Africa.

We know that access to energy is essential for the reduction of poverty and promotion of economic growth. Communication technologies, education, industrialisation, agricultural improvement and expansion of municipal water systems all require abundant, reliable, and cost-effective energy access (UNDP, 2001). Distributed generation using renewable energy systems is one of the best practical solutions to meet rural electrification needs (World Bank, 2000). Since Africa has immense renewable energy resources, making full use of these resources in rural areas, African nations can protect their people, their environment, and their future economic development (Zane Jobe, 2006).

Although there has been rapid development of African economies in recent years, African development still faces many problems, such as a lack of adequate road networks and smart grid, conflict between environmental protection and economic growth, the rising of energy consumption, the trade deficit of fossil energy is widening and the situation of energy security is worsening. These problems are key factors that constrain the development of Africa in general, but can also become important driving forces to promote low-carbon development in Africa. In recent years, many countries invested a lot of money in the field of low-carbon and significantly reduced the unit costs of low-carbon technologies for widely used sources; these will help to combine the international capital and technology with African resources and markets, potentially stimulating low-carbon development in Africa.

In recent years, China-African low-carbon co-operation has become an important component of China-Africa co-operation. In the 4th ministerial meeting of the Forum on China-Africa Cooperation (FOCAC), China proposed eight new measures to promote China-Africa co-operation. As the first of the eight new measures, China proposes to establish a China-Africa partnership in addressing 
climate change. China would enhance co-operation on satellite weather monitoring, development and utilisation of new energy sources, prevention and control of desertification and assist with urban environmental protection. China has decided to build 100 clean energy projects for Africa covering solar power, biogas and small hydro-power. With the rapid development of the world's low-carbon economy and the strengthening of China-Africa co-operation, China-Africa co-operation in the field of low-carbon face broad prospects for co-operation, and better opportunities for development; of course it is also facing some difficulties and challenges.

\section{Current status of China-African low-carbon co-operation}

At present, China-African low-carbon co-operation is still at a preliminary stage. To varying degrees, China and different African countries do have a number of cooperation agreements in low-carbon fields, and the number of projects is constantly growing. Within the framework of FOCAC, China and African countries together held the China-Africa Environmental Protection Co-operation Meeting, implemented the China-Africa human resource training program for environmental protection, and set up the UNEP China-Africa Environmental Center. The Chinese government has proposed to form a partnership between China and African countries in addressing climate change, and strengthen co-operation in different fields. China and African countries have also held in-depth exchanges of views on environmental issues such as international negotiations on climate change to safeguard the common interests of developing countries. The Chinese government has promised not to contend for financial assistance with African countries, but instead will offer them, on the basis of their needs, practical assistances in funds, technology and capacity building in adapting and mitigating climate change.

In recent years, China has carried out a series of projects in the fields of hydropower, biogas technology, solar power and wind power with some African countries. 


\section{Hydropower}

China's low-carbon investment in Africa is mainly in the field of hydropower development. China has some advantages in hydropower technology and Africa has abundant hydropower resources. China has invested in more than 10 African countries' hydropower projects. The total investment in these projects has been more than US\$ 5 billion, China's investment of more than US\$ 3 billion. The largest hydroelectric project under construction is Nigeria Manmubila hydropower project expected to generate 2,600 MW of power in 2018. The followed hydroelectric project is the Merowe dam in Sudan with a hydro-power capacity of $1250 \mathrm{MW}$. In Zambia, too, more than 1,000 MW of hydropower capacity is being developed between the Kafue Lower Gorge and Kariba North projects (Vivien Foster, 2009). Co-operation projects include Mphanda Nkuwa dam on the Zambezi River in Mozambique, Congo River Dam in the Republic of Congo and Bui Dam in Ghana. In April 2012, two hydropower projects have started construction, one is Guinea's largest hydropower project, Keller tower Hydropower, the other is a water conservation project at Côte-d'Or in central Mauritius - much of the cost will be provided by China at low interest rates.

The co-operation of small hydropower between China and African countries is mainly implemented by the International Center on Small Hydro Power (ICSHP) under the "light up Africa" project. China will construct 100 village-level small hydropower stations in 10 African countries (Cameroon, Ethiopia, Kenya, Liberia, Mali, Nigeria, Sierra Leone, Uganda, Zimbabwe, Zambia), to provide electricity for rural communities in Africa, benefiting a population of up to 100,000 people. China will become involved in six African countries, Sierra Leone, Zambia, Zimbabwe, Cameroon and Nigeria to build demonstration projects of small hydropower stations in each country, to promote local social and economic development, and over 300,000 people will directly benefit from this activity (CSTEC, 2011).

\section{Biogas technology}

China has sent biogas experts to some African countries, since the 1980s, to promote biogas technology, to implement many biogas projects that were organised 
by the United Nations, aided by the Chinese government, and for bilateral cooperation. These projects included rural household biogas, large biogas, biogas power generation, urban domestic sewage treatment, the establishment of a national biogas laboratory, biogas resources survey, the development of national biogas development strategic planning and the organisation of various technical personnel training courses (Zhang Mi, 2009). In October 2011, the Chinese Embassy in Sudan donated 25 sets of household biogas devices to the Ta Bate village at White Nile State for the development of animal husbandry (Wu Wenbin, 2010).

The biogas co-operation between China and Africa can be divided into two kinds: one is the factory/farm waste biogas power generation project; the other is rural household biogas technology. The first one can reduce environmental pollution and reduce costs. The second one not only helps to solve the problem of electricity in rural Africa, but is also beneficial to reduce environmental pollution. According to World Bank statistics, three-quarters of households in sub-Saharan Africa, about 500 million people, do not have access to electricity, accounting for a US\$ 38 billion loss to Africa in total each year.

Case I: China's biogas technology assistance projects to Tunisia

From 1998 to 2005, a company in Sichuan province of China has successfully implemented three China-Tunisia biogas technology co-operation projects. The content of these projects include: the general contractor of the biogas power generation demonstration projects, technical training, the establishment of a national biogas laboratory and assistance to develop a national biogas strategic planning capacity.

Case II: Tanzania sisal waste biogas power generation project

This project is a demonstration project of the United Nations Industrial Development Organization (UNIDO) and is the world's first sisal waste to produce biogas and power generation project, completed by the Chengdu Institute of Biology, Chinese Academy of Sciences in co-operation with the German BEB Company.

The project is located in Hale town, Tanga City of Tanzania, with waste residue 
from the Hale sisal processing plant. It generates about $3000 \mathrm{KWh}$ electricity per day and meets the electricity demand of around 300 families. It can also provide a certain amount of cooking energy, and produce about 60 cubic meters of organic fertiliser every day to promote the development of local agriculture.

\section{Solar power}

In recent years, China has developed a variety of solar technologies and products, the quality and quantity of both are at or near the advanced international level. Many China-Africa co-operation agreements have been reached in this field. China plans to build solar power projects in 40 African countries in order to reduce Africa's dependence on fossil fuels, and open a new markets to Chinese manufacturers (China Plans to Light Up Africa with Solar, 2011). Solar water heaters and solar cookers can be widely used in the African regions and China has some advantages in these areas.

In June 2011, China's Ministry of Commerce made a feasibility study on solar energy demonstration projects in Sudan, intended to provide a number of solar street lights for Sudan. In August 2011, Sponsored by the Chinese Ministry of Commerce, Gansu Natural Energy Research Institute hosted the 2011 Frenchspeaking African countries 5 solar energy application technology training classes in Lanzhou. 28 participants engaged in 56 days training coming from 12 countries including Algeria, DRC, Burundi, Senegal, Côte d'Ivoire and Congo-Brazzaville.

\section{Wind power}

China and many African countries have abundant wind resources. This provides a broad platform for China-Africa co-operation. In recent years, China's wind power technology continues to progress and the utilisation of China's wind power is gradually improving. Wind resources in Africa are also very rich, accounting for 20 per cent of the world's wind power capacity (Xinhua News, 2009). At present, the world's fifth largest wind turbine manufacturers - China Goldwind Science \& Technology Co., Ltd. set up offices in Cape Town, South Africa, trying to increase the development of wind energy markets in Africa (China's Commerce Ministry, 
AFRICAN

EAST-ASIAN

AFFAIRS

THE CHINA MONITOR

2011).

\section{Challenges of China-African low-carbon co-operation}

Developed countries are dominating core low-carbon technologies, and the existing international mechanism puts developing countries in a disadvantaged position

In recent years, the United States of America (US), European Union (EU), Japan and other major developed countries have started the implementation of lowcarbon economic development strategies. Low-carbon technologies in developed countries have been taking the lead in the global markets and pose a great challenge for developing countries. An example of this is electric vehicles - Chinese companies have indicated that they do not have independent capabilities in key technologies and systems to produce electric cars.

Currently international low-carbon co-operation has three characteristics:

1. The developed countries have control over the core technologies of lowcarbon, and grasp the right to speak on the international mechanisms

2. Low-carbon co-operation projects are conducted mainly among developed countries, and their technologies are more mature than in developing countries

Developed countries are also dominating the co-operation between the global North and the global South, leaving developing countries in a passive, dependent status

The advantages of the developed countries fall in the areas of investment, technology and other aspects. To some extent it compressed China's space of low-carbon co-operation with Africa. These constraints will inevitably be a big challenge for China if it is to assist in developing low carbon markets in Africa.

Both China and Africa need to transform from high-carbon development to lowcarbon development

The key to achieve low-carbon development is to change the mode of economic 
development, reduce the dependence on coal, oil, natural gas and other fossil fuels. To achieve this, promotion of economic growth that gets rid of high-carbon energy dependence in the process of industrialisation and urbanisation and achieves the transition from high-carbon development to low carbon development is needed. However, China and African countries are still in the framework of the traditional development mode, meaning that changing to energy efficiency is very hard. China and Africa is still in the process of industrialisation and urbanisation. Lowcarbon development cannot be completed within a short time. Even the African's most developed economy, South Africa, is still busy with the process of industrialisation and urbanisation.

The main advantage of many African countries in attracting foreign investment is its rich natural resources, especially oil resources. This forms the economic basis of many African countries. Although low-carbon development in China and Africa has made some achievements there is still a long way to go.

China-Africa economic co-operation is still mainly in the area of trade and lowcarbon co-operation between the two sides is difficult to achieve. Since the founding of the Forum on China-Africa Co-operation (FOCAC), China-Africa relations have witnessed rapid development, but bi-lateral economic co-operation is mainly in resource development and the in the trade of consumer goods. The amount of China's FDI in Africa is rising, but the investment structure, if renewable energy growth is to be achieved, needs to be optimised.

In addition, population growth is a major constraint on China and African countries in achieving low-carbon development. Many African countries have a high rate of population growth, this is bound to have a negative impact on economic growth, increased environmental pressures, increase carbon emissions, and to as a result restrict the low-carbon development co-operation.

Currently, low-carbon development is not the priority for most African countries. The continent needs more electricity to power its economic development

For most African countries, the most important task is to develop their economies 
and to improve the living standards of citizens. For Africa to achieve low carbon development, there are many difficulties:

1. Firstly, Africa's economic structure is still in the transition stage from preindustrialisation to industrialisation. Africa needs more electricity to meet its rising power demand; low-carbon development is not an urgent need for most African countries.

2. Secondly, low-carbon development is a systematic project and cannot be finished overnight and the current energy shortages already limit development.

Thirdly, the lack of capital and technology is another bottleneck for African countries. Low-carbon development requires a lot of money and advanced technologies, especially in the long-term, and sustained investment is needed to ensure sustainable benefits.

It is difficult for China to develop a long-term low-carbon co-operation strategy with African countries. Most of the low-carbon co-operation is attached to other projects, or some small scattered projects. Usually it is a part of China's assistance projects to Africa, or a part of some enterprises' individual business activities, and it is difficult to form the mechanism of low-carbon development co-operation.

In addition, China now is at the top of the list of $\mathrm{CO}_{2}$ emitting countries, and China and African countries do not necessarily have the same view in international climate negotiations.

\section{China and African countries need to deal with the inequalities and imbalances} of the existing international system regarding low-carbon development

Many developed countries are unwilling to assume the obligations, and place a greater emphasis on developing countries to achieving low-carbon development. Developed countries are largely responsible for the causes of climate change to date, but future responsibility is shared by developed and developing countries alike. Rapidly developing countries such as China with steeply rising emissions curves must also actively participate in the much needed transition to low-carbon 
development. The development of low-carbon co-operation between China and Africa will be subject to the imbalance of international mechanisms and cannot necessarily take advantage of the characteristics of both sides to co-operate.

China-African low-carbon co-operation has just started; the capabilities of technological transfer and market operation of both sides need to be further improved

In the process of co-operation, Chinese companies need to learn more about the realities of African countries. This is a disadvantage of Chinese companies compared to Western multi-nationals, which have been operating in Africa since long before Chinese companies.

\section{Prospects of China-African low-carbon co-operation}

When analysing the status and challenges of China-African low-carbon cooperation, it is important ot understand that mutual benefit in the long term is essential. Currently, China has become Africa's largest trade partner, and Africa is now a major resource import market for China, its second largest overseas construction project contract market and China's fourth largest investment destination (in terms of regions). China-Africa economic and trade development has improved people's livelihoods and diversified economic development in African countries, it has provided strong support for China's socio-economic development, and contributed to promoting South-South co-operation and balanced world economic development.

The world's transition from high-carbon development to low carbon development is a strategic opportunity for China and African countries to change their economic growth mode

The world's current economic development mode is a high-carbon mode. This economic mode is based on coal and oil as the main source of energy. However, fossil fuels damage the environment which has an effect on human security. With the continuous expansion of the socio-economic scale, this high-carbon development mode is not sustainable. It is likely to cause serious destruction of the ecolog- 
ical environment, and will affect the sustainable development of human society.

In the future, our world's economic development mode will gradually change from high-carbon to low carbon, and China is trying to begin this transition. Such a transition would also be an essential part of China's modernisation. China can make these emissions reductions within the tight constraints of a global $2^{\circ} \mathrm{C}$ target while still meeting development and economic growth goals over the next four decades.

Low-carbon transition presents opportunities for China and African countires to improve their energy security and move their economies up the value chain in the production of international goods and services. In recent years, the international community has done much work to control greenhouse gas emissions, undertaken many research studies and developed new low-carbon technologies. This trend indicates that the low-carbon development is a new economic growth point and is the next strategic high point of the international competition. It is also an important strategic opportunity for China and African countries to change their growth mode.

China-African low-carbon co-operation is highly complementary in the field of capital, technology, resources and markets, so China-African low-carbon cooperation will have broad prospects in the future

We know that energy shortages have limited Africa's the economic development. Efforts to stimulate economic growth in all industries across the continent are being stifled by the lack of reliable electricity. With sub-Saharan Africa needing $270 \mathrm{GW}$ of additional electricity generation capacity to meet its rising power demand, opportunity exists to use Africa's readily available resources such as hydro, gas, coal and other renewable energy resources (Moses Duma, 2009).

African countries are very eager to use small-scale renewable energy technology. Currently, many countries have invested heavily to develop small-scale solar, wind, and hydropower in a bid to provide energy to urban and rural populations. These types of energy production are especially useful in remote locations because 
of the excessive cost of transmitting electricity from large-scale power plants.

In recent years, China has already made considerable progress in developing lowcarbon technologies in a wide range of sectors, especially in the optimisation of energy structures. Policies and innovation strategies that encourage green innovation and investments are being introduced. China has accumulated many advanced technologies and a great deal of experience in the development of energy efficiency and of clean and renewable energy. These technologies are appropriate, cheap, effective, and suitable for application in African countries.

\section{Prospects in solar power}

Africa has immense solar resources. The distribution of solar resources across Africa is fairly uniform. Africa's 80 per cent land can receive about $2000 \mathrm{KWh}$ of solar energy per square meter per year. Many African countries receive on average 325 days of bright sunlight per year. This gives solar power the potential to bring energy to virtually any location in Africa without the need for expensive large scale grid level infrastructural developments. However, currently with $15 \mathrm{GW}$ installed global capacity solar photovoltaic, Africa only accounts for $15 \mathrm{MW}$. South Africa has some of solar cell manufacturing plants, but production capacity at these plants are very limited. At present, the majority of Africa's large-scale solar power generation facilities are mainly concentrated in South Africa and Algeria.

China has become one of the biggest countries of solar energy utilisation in the world, and China is a leading player in some solar energy technologies. Solar power in China is a growing industry. China is the world's largest user of solar hot water systems. The number of China's solar water heaters ranked first in the world. In 2009, the annual production of solar water heaters in China exceeded 40 million square meters, accounting for 50 per cent of world production, the total installed number has reached 145 million square meters, accounting for about 70 percent of world installation. In solar cell technology, China's photovoltaic battery output in 2011 accounted for about 50 percent of global output, ranking first in the world for five consecutive years. 
China enjoys advantages in large-scale as well as small-scale solar power generation technologies. These technologies can be used to generate power on a large scale and can be used to provide power on a smaller scale, helping with day to day needs such as small-scale electrification, desalination, water pumping, and water purification.

\section{Prospects in wind power}

Africa's wind resources are the best around the coasts and in the eastern highlands. Wind is far less uniformly distributed than solar resources. The availability of wind on the western coast of Africa is substantial, exceeding 3,750 KWh, and will accommodate the future prospect for energy demands. Central Africa has lower than average wind resources to work with. It is in Mediterranean North Africa that wind power has been developed at scale. This, too, is where current national policies are set to grow the sector further. At the end of 2009, about 96 per cent of the continent's total wind installations of $763 \mathrm{MW}$ were to be found in Egypt (430 MW), Morocco (253 MW) and Tunisia (54 MW).

In 2010, China's new installed wind power capacity was $18.9 \mathrm{GW}$, and the total installed capacity has reached $42 \mathrm{GW}$, the largest in the world. Targets for individual low-carbon technologies have repeatedly been revised upwards as development outstripped expectations. Wind power growth has caught particular attention - with capacity rising from $13 \mathrm{GW}$ in 2008 to $42 \mathrm{GW}$ in 2010 (equivalent to half the power plant capacity in the UK in 2010). China plans to achieve $100 \mathrm{GW}$ of wind power capacity by 2015 .

Yet in term of technology, China's wind power development lags behind European countries. China's home-grown wind turbine manufacturers such as Goldwind and Sinovel are however amongst the world's top five producers, and produce wind turbines based on domestically-developed intellectual property, with the intention of creating an export market in Europe. Chinese companies have the ability to constantly move from "Made in China" to "Created in China" and from the domestic market to the international market. 


\section{Prospects in hydropower}

Africa's hydropower resources have the potential to significantly contribute to solving the region's power problems. Sub-Saharan Africa has a tropical climate and a significant number of perennial rivers, with a potential to generate 1,750 $\mathrm{TWh}$. The resource uses proven technology and is easily accessible across the region. However, only 7 per cent of this potential has been developed. The exploration of key rivers such as the Zambezi, Congo, Nile, and Niger could provide a solution to Africa's power problems. The Congo River in DRC has the potential to produce over 100,000 MW of electricity, which is sufficient to meet the energy needs of the whole Southern Africa. The Zambezi River can produce 10,000 MW. Other examples include Ethiopia, with a hydro potential of 30,000 MW, and Nigeria with over 20,000 MW (Moses Duma, 2009).

China's hydropower industry has three major advantages (low cost, skills, the nation's "go-out" strategy), and has a clear competitive advantage in the global markets. The Chinese Export-Import Bank and other Chinese financial institutions, state-owned enterprises, and private firms are now involved in at least 100 major dam projects overseas. Hydropower is readily available in many African countries, for both large and small scale projects. Hydropower is highly versatile and can be used to meet national electricity grid requirements, rural electrification programs and industrial power needs. Therefore, the hydropower co-operation of China and African countries have broad prospects for the future. It can solve Africa's three problems (electricity, irrigation and water shortage) in one fell swoop.

\section{Although China has a technological gap compared with developed countries, China can continue to reduce the cost of low-carbon products through econo- mies of scale, also reducing the cost for African countries}

Low-carbon products are expensive. Even when the relative difference in buying power, materials cost, opportunity cost, labour cost and overhead are factored in, renewable energy will remain expensive for people who are living on less than US\$ 1 per day. 
In recent years, China has been increasing investment in low-carbon development. China has ranked first in the list of largest clean energy investors in 2010, when investment in China reached US\$ 54 billion, with Germany in second place (US\$ 41 billion) and the USA in third (US\$ 34 billion). China can continue to reduce the cost of low-carbon products by the scale effect of China's huge market, and in doing so provide a safe, reliable and cost effective solution for Africa's rural areas.

Cheaper equipment is also more secure and less vulnerable to attack. This can be an important feature in regions prone to conflict. Cheaper wind and solar power systems are simple to set up, easy to operate, easy to repair, and durable. Wind resources and solar resource are abundant enough to provide all of the electrical energy requirements of rural populations, and this can be done in remote and otherwise fragmented low density areas that are impractical to address using conventional grid based systems (Howells, 2003).

\section{Conclusion and recommendations for China-African low-carbon co-operation}

There are three obstacles in promoting low-carbon development in the subSaharan African region: cost, market structure and risk. In rural areas of subSaharan Africa, less than 10 per cent of households can connect to the electricity grid. Using small-scale wind, biomass and solar systems in rural areas of Africa can reduce costs, and make it easier to expand the existing grid. Structural defects in the African energy market, including corporate monopolies, discourage new investment and the entrance of new technology into the market. This requires government reform of energy management systems to encourage third parties and private power producers to enter the low-carbon market. At the same time, using some risk mitigation tools to deal with political risk, regulatory risk and business risk in the sub-Saharan African region. From the perspective of China-Africa cooperation, the obstacles should be combined with the experience of China-Africa co-operation, and the promotion of the China-Africa energy low-carbon cooperation in the following fields: 
China's investment in clean energy over the years

\begin{tabular}{|c|c|c|}
\hline Year & $\begin{array}{l}\text { The } \\
\text { amount of }\end{array}$ & Important feature \\
\hline 2013 & $\begin{array}{l}\text { US\$ } 54.2 \\
\text { billion }\end{array}$ & $\begin{array}{l}\text { China solidified its position as the world's clean energy } \\
\text { superpower. China maintains the world's most robust } \\
\text { wind market. China accounted for } 28.7 \text { per cent of G-20 } \\
\text { total spending in renewable energy. } 5 \text {-year growth rate } \\
\text { is } 17.8 \text { per cent. }\end{array}$ \\
\hline 2012 & $\begin{array}{l}\text { US\$ } 65.1 \\
\text { billion }\end{array}$ & $\begin{array}{l}\text { China garnered } 25 \text { percent of G-20 solar energy } \\
\text { investment, setting a one-year record with US\$ } 31.2 \\
\text { billion, and } 37 \text { per cent of G- } 20 \text { wind energy } \\
\text { investment, with US\$ } 27.2 \text { billion recorded. China also } \\
\text { registered } 47 \text { percent of G-20 investment in the "other } \\
\text { renewable energy" category that includes small hydro, } \\
\text { geothermal, marine, and biomass. }\end{array}$ \\
\hline 2011 & $\begin{array}{l}\text { US\$ } 45.5 \\
\text { billion }\end{array}$ & $\begin{array}{l}\text { China continued to attract significant investment in } \\
\text { wind, which totalled US\$ } 29 \text { billion in } 2011 \text {, spurring } \\
\text { deployment of } 20 \mathrm{GW} \text { of wind capacity. }\end{array}$ \\
\hline 2010 & $\begin{array}{l}\text { US\$ } 34 \\
\text { billion }\end{array}$ & $\begin{array}{l}\text { In 2010, China accounted for almost } 50 \text { per cent of the } \\
\text { global wind and solar industry investment. }\end{array}$ \\
\hline 2009 & $\begin{array}{l}\text { US\$ } 34.6 \\
\text { billion }\end{array}$ & $\begin{array}{l}\text { China has become the top of the list of clean energy } \\
\text { investment, }\end{array}$ \\
\hline 2008 & $\begin{array}{l}\text { US\$ } 12.8 \\
\text { billion }\end{array}$ & $\begin{array}{l}\text { The growth rate of China's investment in wind power } \\
\text { market has been ranked second in the world; } \\
\text { investment in solar power generation has become the } \\
\text { first in the world. }\end{array}$ \\
\hline 2007 & $\begin{array}{l}\text { US\$ } 10.8 \\
\text { billion }\end{array}$ & $\begin{array}{l}\text { Most of the funds have been invested in to increase the } \\
\text { installed capacity of wind power. The installed capacity } \\
\text { is twice that of } 2006 \text {. }\end{array}$ \\
\hline
\end{tabular}


AFRICAN

\section{Assistance to Africa}

China should further increase assistance in the field of appropriate low-carbon technologies and green agricultural technologies to Africa, making it a highlight of the China-African low-carbon co-operation. This will help improve the effectiveness and reputation of China's assistance.

Chinese finance often goes to large-scale infrastructure projects, with a particular focus on buildings, hydropower generation and railways. More than 35 African countries are engaging with China on infrastructure financial assistance, with the biggest recipients being Nigeria, Angola, Sudan, and Ethiopia. China could further increase assistance in the field of low-carbon appropriate technologies and green agricultural technologies. On the one hand, this can spread China's low-carbon technologies and products to the African market, and on the other hand, it can diversify the forms of China's assistance to Africa.

\section{Technical co-operation}

Technical co-operation should include establishing an effective mechanism of China-Africa technical co-operation through the combination of China's advantages in technology and capital with Africa's advantages in low-carbon resources and labour; and, establishing a China-Africa Technical Co-operation Fund, to promote the application and transfer of low-carbon technologies in Africa to ensure that African countries can get China's low-carbon technologies at reasonable costs. In the long run, China-Africa low-carbon technology transfer can help improve Africa's investment environment and form the industrial chain between China and Africa.

\section{Chinese government}

In order to better integrate China's advantageous resources in low-carbon, and help China's low-carbon businesses to invest in Africa, the Chinese government should formulate strategic plan and provide the necessary support and services for China's companies in Africa to reduce risk. 


\section{Formulating China's long-term low-carbon investment plan in Africa}

On the basis of analysis of the advantages of both sides, African governments, in corporation with China should formulate a long-term low-carbon investment plan in Africa for China. The plan should have a clear choice on the location and industry of China's investment in Africa and set out some preferential policies for China's companies in Africa. In the choice of location (from the Chinese side), China should give priority to the African countries that have low-carbon resources, preferential policies and friendly relations with China. In the choice of industry, China should give priority to the industries that will be most suitable for the actual on the ground situation in Africa and are able to take advantage of Africa's low-carbon resources and China's technologies.

The Chinese government and Chinese financial institutions should support Chinese low-carbon companies to invest in Africa:

1. Financial organisations and policy banks in China should increase the loan amount, and to provide Chinese companies with good financial support, reduce the overall costs of the enterprise, enhance the competitiveness of enterprises.

2. China's commercial banks and private capital should be encouraged to invest in Africa's low-carbon field, getting the support from the venture capital funds and opening up channels for international financing. In addition, in order to reduce the investment risk, China should establish overseas investment insurance systems as soon as possible and help enterprises avoid risks and improve project success rates.

3. An expert advisory committee for China-African low-carbon co-operation should be established. It will serve the major projects of China's low carbon companies in Africa, and provide decision-making advisory services and technical guidance for these companies.

A China low-carbon Enterprise Development Association should be established to co-ordinate China's low-carbon development. At present, many of China's low 
carbon enterprises lack international business experience and are is still only in the initial stages of becoming transnational businesses.

\section{Chinese enterprises}

In recent years, Chinese investment in Africa has grown rapidly, however this is still limited in comparison to the potential. Many Chinese low carbon businesses are willing to go out, but they are not familiar with the investment environment in Africa and lack the necessary experience of overseas investment.

As a type of market-seeking investment, China low-carbon companies should clearly understand their investment target in Africa and have a long-term strategic investment plan. At present, most of China's enterprises in Africa are resourceseeking enterprises, they lack the long-term business objectives and generally hope to have "bigger economic returns and smaller investment", and lack the long-term strategic considerations in the African market.

These companies should do market research and project feasibility analysis. The situation in Africa is complex, companies should not blindly implement crossborder investment and operation. A comprehensive understanding of the African country's political, economic, and cultural knowledge is necessary. They should fully estimate the political risk and economic risk and make the right investment decision.

The Chinese low carbon companies should speed up the indigenisation process of their businesses in terms of market, management and capital.

Overall, China's investment in Africa contains both risks and opportunities. Chinese enterprises should actively and safely deal with the short-term risks, and seize the long-term opportunities. When analysing the four main motivations of investment (cheap labour, local market, supply of raw materials and abundant natural resources), Africa's huge population, markets and resources are incomparable advantages to attract low-carbon FDI in the future. This requires China to careful analyse the situation of the various development stages, and combine China's lowcarbon investment projects in Africa with the elements of China's traditional 
strengths, special resources, and competitive enterprises. In the process of lowcarbon co-operation, China-African low-carbon co-operation faces a monumental challenge and a historic opportunity. The transition to a low-carbon economy will require large investments and advanced technologies but will also bring about substantial benefits.

The path of low-carbon development not only creates a viable method for solving the global development predicament, but brings strategic opportunities to the majority of the developing world to achieve leapfrog development. If Africa wants to take advantage of this rare strategic opportunity, the future reform is essential. Firstly, low-carbon development for Africa is needed to achieve leapfrog development and it has important strategic significance. African governments should develop low-carbon development goals and give priority to low-carbon development. Secondly, Africa should exploit the advantages of resources rather than simply exporting raw materials to the developed economies or fast-growing emerging markets. African countries should strive to break the monopoly and national protectionism and create conditions for sustained external capital and technology in the field of low-carbon technologies and industries to strengthen African new energy industries. Thirdly, low-carbon development will help African countries to achieve economic diversification. Diversification is a sign of maturity of an economy. African countries can rely on low-carbon development as an opportunity to adjust and optimise their industrial composition. Fourthly, Africa's development requires a lot of investment to electrify Africa, especially in rural areas. Lowcarbon technologies can provide localised off-grid solutions that provide electricity to off-grid areas. This requires the government to encourage third parties and private-power-producers to enter the low-carbon market and reduce business risk.

The widespread use of mobile phones helped Africa leapfrog the wired telephone era and achieve development through a new technology; low-carbon development can help African countries to break through the bottleneck restricting development in the form of energy shortages. The solution to the problem is complex, but China -African low-carbon co-operation will help solidify the foundation of Africa's economic development, increase investment in infrastructure construction, 
AFRICAN

transport, manufacturing and small and medium-sized enterprises. In addition it will increase Africa's capacity for independent development. Capital, equipment and technologies from China have effectively helped and will continue to reduce construction costs for African countries and improve their infrastructure situations.

\section{Bibliography}

China Plans to Light Up Africa with Solar. 2011. [Online]. Available: http:// www.iol.co.sa/business/international/china-plans-to-light-up-africa-withsolar-1.1080600 [2014, April 10].

China's Commerce Ministry. 2011. Chinese Wind Power Companies Targeting the African Market [Online]. Available: http://www.mofcom.gov.cn/aarticle/i/ jyj1/k/201103/20110307450321.html [2014, April 10].

CSTEC (China Science and Technology Exchange Centre). 2011. South-South Cooperation on Science and Technology to Address Climate Change Applicable Technology Manual. [Online]. Available: http://www.actc.com.cn/ UpLoadFiles/Attached/file/20120605/20120605105916_4745.pdf [2014, April 10].

Duma, M. 2009. Hydropower: Africa's Solution to the Electricity Crisis! [Online]. Available: http://www.frost.com/prod/servlet/market-insight-top.pag? docid=169253081[2014, April 10].

Foster, V. 2009. Building Bridges-China's Growing Role as Infrastructure Financier for Sub-Saharan Africa. The World Bank's Trends and Policy Options. No.5: 21.

Howells, M. I. et al. 2003. An Energy Model for a Low Income Rural African Village. [Online]. Available: http://www.etsap.org/ worksh_6_2003/2003P_howells.pdf [2014, April 10].

Jobe, S. 2006. Alternative energy sources for electricity generation: Their 'energy 
effectiveness' and their viability for undeveloped and developing countries. [Online]. Available: http://www.ecoguinea.org/uploads/5/4/1/5/5415260/ alternative_energy_sources_for_electricity.pdf [2014, April 10].

Shang, M. 2009. China Biogas Technology in Africa Retrospect and Prospect [Online]. Available: http://www.newenergy.org.cn/ Html/0094/4140926551.html[2014, April 10].

UNDP (United Nations Development Programme). 2001. The Human Development Report 2001. [Online]. Available: http://hdr.undp.org/reports/ global/2001/en/ [2014, April 10].

Wenbin, W. 2010. The Biogas Lamp Lights White Nile [Online]. Available: http:// env.people.com.cn/GB/12923787.html [2014, April 10].

World Bank. 2000. Expanding Electricity Access to Remote Areas: Off Grid Rural Electrification in Developing Countries. [Online]. Available: http:// www.martinot.info/Reiche_et_al_WP2000.pdf [2014, April 10].

Xinhua News. 2009. More and More African Countries Favour Wind [Online]. Available: http://news.xinhuanet.com/fortune/2009-07/30/ content_11796428.htm [2014, April 10]. 
African East-Asian Affairs

is a quarterly publication of the Centre for Chinese Studies

at Stellenbosch University, Western Cape, South Africa.

Online ISSN : :2308-8699

Editorial Team

Harrie Esterhuyse

Indiana B. Jones

Design \& Layout

Centre for Chinese Studies

\section{Contact Us}

Centre for Chinese Studies

Stellenbosch University

Tel: +27 218082840

Fax: +27218082841

Email: ccsinfo@sun.ac.za

http://aeaa.journals.ac.za - www.sun.ac.za/ccs

B@ocs_stell

f facebook.com/ccs.stell 


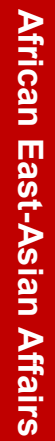

$\bar{g}$
옹

독
Ф
뭉 